Online only at http://www.cahij.com/

\title{
ORTAÇAĞ TÜRK-İSLAM DÜNYASININ DURGUNLUK ÇAĞINDA TIP VE TABABET
}

\author{
(Beylikler ve Erken Osmanlı Dönemi Tababeti)
}

\section{Abdulhalik BAKIR* Muhammed BERBEROĞLU** Çă̆rı BAKIR ${ }^{* * *}$}

\begin{abstract}
Özet
Anadolu'nun farklı yerlerinde kurulan Anadolu beyliklerinin yöneticileri hâkimiyet alanlarında refahı artırmak ve belki de kendilerinden bahsettirerek birbirlerine karşı psikolojik üstünlük elde etmek için yoğun şekli ile ilim adamlarını himaye etmişlerdi. Himaye ile yetinmeyen Beylik yöneticileri, farklı memleketlerde bulunan ilim erbabını ülkelerine davet etmişler ve bu davete icabet eden âlimler önemli iltifatlara mazhar olmuşlardır. Bu durum Anadolu'da ilmi faaliyetlerinin gelişimine önemli ölçüde katkı sağladığı gibi, farklı alanlarda birçok eserin vücuda gelmesini de sağlamıştır. Bu dönem içerisinde tıp alanında birçok eser yazılmış ve bu eserler, genellikle eseri yazan âlimin himaye gördüğü Anadolu Beyliklerinin yöneticilerine ithaf olunmuştur. Bu ve buna benzer tıp bilimi ve çalışmaları ile ilgili faaliyetler Osmanlı devletinin erken dönemlerinde de artarak devam etmiştir. Ancak bu iki dönemde yapılan çalışmalar, daha önceki Büyük Selçuklu dönemi çalışmaları ve daha sonraki Osmanlı devletinin azamet dönemindeki çalışmaları ile mukayese edildiğinde tababet adına çok büyük yenilikler getirmediğine şahit olmaktayız. İşte bu özelliklerinden dolayı da bu döneme "Ortaçağ Türk-İslam Dünyasının Durgunluk Çağı" başlığını kullandık.
\end{abstract}

Anahtar Kelimeler: Ortaçağ, Tıp, Tababet, Beylikler, Osmanlı Devleti

\section{MEDICINE AND DOCTORING IN THE MEDIEVAL TURK-ISLAM WORLD DURING THE STAGNATION AGE}

\section{(Doctoring of the Principalities and Early Ottoman Period)}

\begin{abstract}
The rulers of the Anatolian Principalities, established in different parts of Anatolia, to increase welfare and perhaps to gain psychological superiority towards each other by making talk about themselves, they intensely patronized the scholars. The rulers of the Principalities who were not satisfied with patronage, invited the scholars from different countries to their realm and the scholars that responded to that invitation had received crucial compliments. This situation contributing significantly to the development of scientific activities in Anatolia as well as it had also enabled many studies to be formed in various fields. During that period numerous works in the field of medicine were written down were generally dedicated to the master of the Anatolian Principalities that patronaged the author of that work. Activities, about medical science that were similar to this study, continued to grow at the early stages of the Ottoman Empire. But when we compare the studies of

\footnotetext{
* Prof. Dr. Bilecik Şeyh Edebali Üniversitesi, Fen Edebiyat Fakültesi, Tarih Bölümü Öğretim Üyesi.

** Tonya (Trabzon) Halk Eğitim Merkezi Müdürü, Fırat Üniversitesi Sosyal Bilimler Enstitüsü Tarih Anabilim Dalı, Yüksek Lisans Mezunu.

*** Doktota Öğrencisi, Hacı Bektaşi Veli Üniversitesi Sosyal Bilimler Enstitüsü Tarih Anabilim Dalı.
} 
ISSN-2199-353X

Online only at http://www.cahij.com/

those two periods with the periods of the Great Seljuk and the magnificant era of the Ottoman, we are witnessing that they do not bring great innovation for the name of doctoring. That was because of these characteristics, we have used the title "The Stagnation Age of the Medieval Turk - Islam World".

Keywords:Middle Ages, Medicine, Doctoring, Principalities, Ottoman Empire.

\section{Giriş}

Hastalıklar ve tedavi yolları, tarih boyunca insanların çözmeye çalıştığı öncelikli meselelerin başında yer almıştır. İlk insan topluluklarında hastalık nedenleri doğaüstü sebeplere bağlanır ve hastalıkların, tabuların bozulmasına dayalı olarak gücenen tanrılar tarafından gönderildiğine inanılırd ${ }^{1}$. Tedavi yöntemleri de buna bağlı olarak ruh dünyasına hitap edecek şekilde dinsel bir algılama ile büyüsel yöntemler kullanılarak giderilmeye çalışılırdı. Bu nedenle de eskiçağ insanları yakalanmış oldukları hastalıkları, tabiatta bulunan farklı madde ve bitkilerin gücünden yararlanarak tedavi etmeye çalışırlardı. İnsanoğlunun yeteneklerini geliştirme sürecinde geleneksel yöntemlere başvurduğu da bir gerçektir. Kendisi ile beraber aynı dünyayı paylaşan canlıların kendi kendilerini tedavi etme yöntemleri insanoğlunun hastalıklarla olan mücadelesinde ilham kaynağını teşkil etse gerektir $^{2}$. Diğer bilim dallarında olduğu gibi tıp alanında da insanoğlu farklı topluluk ve medeniyetlerin ortak mirasının paylaşımcısıdır. "İlmin vatanı yoktur, ancak her âlimin vatanı vardır"3 sözü diğer bilim dallarında olduğu gibi tıp tarihinin de gelişim sürecini ifade etmektedir. Tıp tarihine ait en eski belgeler mağara duvarlarına çizilmiş olan resimler, şekiller ve destansı bilgilerdir.

Mezopotamya'da Sümerlerin yazıyı icadıyla birlikte dünya tarihinde yeni bir kapı açılmıştır. Bilgilerin ve de bilgisel uygulamaların yazıya dökülmesi ile insanlık tarihinin kalıcı hafızası oluşmaya başlamış, bu da bilimin gelişmesine önemli ölçüde katkı sağlamıştır. Tıp tarihinin de ilk yazılı kaynakları belirtilen dönemden itibaren farklı yazı stilleri ile kayıt altına alınmıştır. Öyle ki; ilk çağlardan bu yana çeşitli hastalıkların tedavisi için uğraş verenler, hastalara ve yaralılara uyguladıkları tedavi, teknik ve yöntemlerini çeşitli yazı biçimleri ile belgeye dönüştürmüşlerdir ${ }^{4}$.

Tıp alanıyla ilgili İslam öncesi Türk tarihine ait ilk yazılı kaynakları, Uygur tıp metinleri oluşturmaktadır. Bahsi geçen döneme ait kırk beş belge ve belli bölümleri eksik bir kitaptan oluşmakta olup günümüze kadar ulaşmayı başarmıştır ${ }^{5}$. İslam öncesi dönemde Orta Asya'da yaşayan Türk toplulukları da hastalıkları ve tedavi yollarını, ilkel topluluklarda olduğu gibi dinsel ve büyüsel nedenlere dayandırıyorlardı. Bu durumuyla da göçebe bozkır kültürünü yaşayan Türk topluluklarında bilime dayalı bir tıp anlayışının varlığından söz etmek mümkün değildir. Ancak geleneksel halk hekimliği içerisinde sınırlı da olsa bazı tedavi yöntemlerinin ortak olarak kullanıldığı söylenebilir. Örneğin, Türklerin bilinen ilk devleti olan Asya Hun Devleti'nde bir tedavi yöntemi olarak hastalanan kişinin karın bölgesine kızdırılmış taş koymak veya toprağı ateş yakarak 1sıtıp, ısınan toprağın üstünü yatırmak suretiyle tedavi edilmeye çalışılırdı. Bazen de ağrılı bölgelerin üzerindeki damarlar çizilir ve oradan kan akıtılarak ağrı dindirilmeye çalışılırdı ${ }^{6}$. Bunun yanında yaygın olarak halk hekimliğinden ve

\footnotetext{
${ }^{1}$ Erdemir, A. D. Erdemir, Tip Tarihi Ve Deontoloji Dersleri, Bursa, 1994. s. 11.

${ }^{2}$ Nil Sarı, Tarih Öncesinde Tip, Tip Tarihi ve Tip Etiği Ders Kitabı, İstanbul, 2007, s. 5.

${ }^{3}$ Ali Haydar Bayat, Tıp Tarihi, Merkez Efendi Geleneksel Tıp Derneği, İstanbul, 2010, s. 17.

${ }^{4}$ A. Artukoğlu, A. Kaplan, A. Yılmaz, "Tıbbi Dokümantasyon”, Bilim ve Teknik Dergisi, Haziran 2002, (14). s. 24.

${ }^{5}$ Ali Haydar Bayat, “Uygur Tıp Metinleri”, Tip Tarihi, İzmir, 2003, s. 211.

${ }^{6}$ Aynı eser, s. 238.
} 
dolayısı ile kam ve baksılardan ${ }^{7}$ yararlanılmakta idi. Şamanist inancın İslam öncesi Türk topluluklarında geniş kitlelere hitap ettiği düşünüldüğünde, bu inanç kültürünün temsilcileri olan kamların toplum içerisindeki etkinliğini tahmin etmek zor olmasa gerektir. Uygurların Manihaizm inancına yönelmesi ile kamların yerini bölgesel olarak maniheist rahiplerin aldığı görülmektedir. Türk tarihinde bilinen ilk tıp okulunun da Manihaizm tapınaklarında faaliyete geçtiğini söylemek mümkündür ${ }^{8}$.

\section{Beylikler Döneminde Tıp Çalışmaları}

\section{A. Beylikler Döneminde Siyasî ve İlmî Hareketlilik}

Anadolu Selçuklu Devleti, yarım asırdan fazla sürecek uzun bir dönem Moğol-İlhanlı idaresinde kalmış, Anadolu; siyasi, askeri ve iktisadi yönlerden sıkıntılar çekmiştir. XIII. asrın ortalarından itibaren Moğol istilasının Türkmenler üzerine meydana getirdiği baskı ve zulüm, onların yerlerini ve yurtlarını terk ederek uçlara doğru çekilmelerini sağlamıştır. Ancak bütün bu olumsuzlukların yanında bazı önemli imar faaliyetleri ile Türkmen Beylerinin istiklal arayışları da aynı dönem içerisinde gerçekleşmiştir. Bu istiklal arayışları, uçlarda Türk beyliklerinin doğmasına ve "Anadolu Türklüğünün yeniden canlanmasını sağlamıştır". 1308 yılında son Selçuklu hükümdarının ölümüyle birlikte Anadolu'da da yeni bir dönem başlamıştır. Bu dönem içerisinde Anadolu'nun farklı yerlerinde bağımsız beylikler oluşmuştur. Anadolu'da 14. Yüzyılda kurulan Beylikler ve kuruldukları yerler şöyledir:
1. Karamanoğulları: Ermenek, Karaman ve Konya
2. Eşrefoğulları: Beyşehir
3. Hamidoğulları: Eğridir, Isparta
4. Germiyanoğulları: Kütahya
5. Menteşeoğulları: Milas, Muğla
6. Candaroğulları: Kastamonu, Sinop
7. Pervaneoğulları: Sinop
8. Aydınoğulları: Selçuk, Birgi
9. Ramazanoğulları: Adana
10. Dulkadiroğulları: Elbistan
11. Karesioğulları: Balıkesir
12. Saruhanoğulları: Manisa
13. Osmanlılar: Söğüt, İznik ${ }^{10}$.

Anadolu'nun farklı bölgelerinde bağımsızlıklarını ilan eden Anadolu Türkmen Beylikleri varlıklarını kanıtlamak istercesine kuruluşlarından itibaren yoğun bir imar faaliyeti içerisine girmişlerdir ${ }^{11}$. Bu durum şehirlerin yenileşmesini ve gelişimini sağlarken aynı zamanda, sanat ve ilmi

\footnotetext{
${ }^{7}$ Kam: Doğaüstü güçler tarafından seçilen ve tabiatüstü güçlere sahip olduğuna inanılan kişilere verilen isimdir. $\mathrm{Bu}$ halk hekimleri trans haline geçmek için ilginç hareketler yaparak ruhlar âlemi ile hastalıklı kişi arasında irtibat kurarak kötü ruhların (kara körmös/kara tös/körmöz) kişi üzerinden hastalığın kaldırılması için aracı olduğuna inanılırdı. Baksılar: Kamların İslami dönemde aldığı isimdir.

${ }^{8}$ Ali Haydar Bayat, “İslam Öncesi Orta Asya Türk Dünyasında Tababet”, Türkler, c. III, Ankara, 2002, s. 811.

${ }^{9}$ M. Halil Yinanç, Türkiye Tarihi, Selçuklular Devri I. Anadolu'nun Fethi, İstanbul 1994, s. 75.

${ }^{10}$ Yaşar Yücel, Anadolu Beylikleri Hakkında Araşttrmalar II, Türk Tarih Kurumu Yayınları, Ankara, 1991, s. 934; İsmail Hakkı Uzunçarşı1l, Anadolu Beylikleri ve Akkoyunlu ve Karakoyunlu Devletleri, Türk Tarih Kurumu Yayınları, Ankara 2003, s. XI-XII.

${ }^{11}$ Gönül Öney, Beylikler Devri Sanatı XIV-XV. Yüzyll, Türk Tarih Kurumu Yayınları, Ankara,1989, s. 1.
} 
hayatın da gelişimine katkı sağlamıştır. Anadolu'da XI ve XIII. asırları kapsayan Selçuklular döneminde ilmi alanda ve özellikle konumuzu oluşturan tıp bilimi alanında önemli gelişmeler yaşanmıştı. Bu dönem içerisinde birçok tıp merkezi denilebilecek sağlık kurumları teşekkül etmişti, aynı zamanda birçok ilim adamının ve eserinin ortaya çıkmasını sağlayacak çalışmalara imza atılmışt1 ${ }^{12}$. Selçuklular dönemindeki bu gelişme 1308 yılından sonra Beylikler döneminde de geliştirilerek devam ettirilmiştir. Anadolu Beylikleri, Selçuklulardan almış oldukları büyük mirası kurumsallaştırmayı ve her şeyden önemlisi Türkçenin hâkim olduğu, eserlerin Türkçe yazıldığı bir döneme imza atmayı başarmışlardır. Beylikler dönemi öncesinde yazışma dilinin Arapça ve edebi dilinde Farsça olmasından kaynaklı dönemin hekimleri eserlerini Arapça ve Farsça olarak yazmışlardır. Bilim dilinin Arapça olması nedeniyle de hekimler Arapça öğrenmek, anlamak ve eserlerini bu dilde üretmek zorunda kalmışlard $1^{13}$. Beylikler döneminde Arap kültürünün etkisinin azalması ve Oğuz Türkçesinin yazı dili hâline gelmeye başlaması, tıp eserlerinin yaygın bir şekilde Türkçe yazılması sonucunu beraberinde getirmiştir.

Diğer yandan Selçuklular döneminde olduğu gibi Anadolu Beylikleri döneminde de Beylik yöneticileri hüküm sürdükleri topraklarda ilim ve kültürün gelişmesi için bir takım tedbirler almış ve teşvik edici yollara başvurmuşlardır. Başvurdukları en önemli yol ilmî müesseselerin yapımına ağırlık verilmesi ve çevre beyliklerden ve civar memleketlerden ilim erbabının davet edilmesi usulü idi ${ }^{14}$. Daveti kabul edip gelen âlimler, geldikleri ilim müessesesinin bağlı bulunduğu beylerden iltifat ve geniş ihsan görmüşlerdir. $\mathrm{Bu}$ durum zor şartlarda faaliyet göstermeye çalışan çevre ülke ve topluluklardaki ilim adamlarının Anadolu'ya gelmesini özendirmiş olup, bu politika Beylikler döneminde birçok eserin yazılmasına ve ilmi hayatın gelişimine ciddi anlamda katkı sağlamıştır ${ }^{15}$.

Anadolu Beyliklerinin bazılarının beyleri de ilim ve irfan sahibi kişilikleri ile tarihte iz bırakmışlardır; onların en önemlileri ise şunlardır: Kastamonu hükümdarı Muzafferuddin Yavlak Arslan, Amasya beyi Hacı Şadgeldi Paşa, Sivas hükümdarı Eratna ve Kadı Burhaneddin Ahmed, Aydınoğlu beylerinden Mehmed ve İsa Bey ve Saruhanoğlu İshak Bey. Hükümdarlardan özellikle Sultan Eratna'nın ilmî tartışma meclislerine eşini de iştirak ettirdiği bilinmektedir. Genç yaşta müderrislik, kadılık gibi görevleri müteakip devlet idaresine girerek kendi adıyla tanınacak olan devletin başına geçen Kadı Burhaneddin Ahmed'in ise, haftanın üç gününü ilim adamlarıyla sohbete ayırdığ 1 kaynaklarda zikredilmektedir ${ }^{16}$.

\section{B. Beylikler Döneminde Tababet ve Sağlık Kurumları}

Beylikler döneminde Selçuklu devletinden devralınan miras zenginleştirilerek korunmuş, halkın ihtiyaç duyduğu sağlı hizmetleri yaygınlaştırılarak devam ettirilmiştir. $\mathrm{Bu}$ dönem içerisinde yeni darüşşifaların kurulmasından ziyade hizmet halinde olan darüşşifalar onarılarak geliştirilmiştir. İlhanlıların Anadolu işgalleri döneminde Selçuklu hâkimiyetinin bittiği ve Anadolu'da Beylikler devrinin başladığı 14. yüzyılın başlarında Amasya'da Anber b. Abdullah Dâruşşifâsı yaptırılmıştı

\footnotetext{
12 Geniş bilgi için bkz. Hüseyin Kayhan, "Selçuklular Devrinde Tıp Bilimi ve Hekimler Hakkında Notlar", History Studies, Volume 3/2011, s. 161.

${ }^{13}$ Emel Kay, “Safa Odabaşı’nın Arşivindeki Türkçe Tıp Yazmaları”, I. Edirne Tıp Tarihi Günleri Bildirileri (34 Ekim 2001) "Dr. Rifat Osman Anısına" (1874-1933), (Haz. Ender Bilar), Edirne, 2001, Trakya Üniversitesi Rektörlüğü Yayınları No: 42, s. 383-296.

14 Ekmeleddin İhsanoğlu-Kaçar, Mustafa; “Osmanlı İmparatorluğu'nda Klasik Bilim Geleneğinin Tarihçesi”, Genel Türk Tarihi, C. 6, Ankara 2002, s. 490-491.

15 İsmail Hakkı Uzunçarşı1l, Anadolu Beylikleri ve Akkoyunlu, Karakoyunlu Devletleri, Ankara, 1988, s. 211.

16 İsmail Çiftçioğlu, "Türkiye Selçukluları ve Beylikler Döneminde İlmi Teşvik, İlim Adamlarını Himaye Anlayışı”, Ege Üniversitesi Türk Dünyasını Araştırma Enstitüsü, Türk Dünyasını Incelemeleri Dergisi, Sayı-1 İzmir, 2006, s. 30.
} 
(1308-9). Medrese planında, tek eyvanlı ve 10 odalı olarak yaptırılan darüşşifa döneminin tıp eğitimini sürdürdügü bir okul vazifesi de görmüştür ${ }^{17}$. Aynı dönem içerisinde Karamanoğulları Beyliği zamanında Aksaray'da 1337 yılında bir Dâruşşifâ binası yapıldığı ve kalıntılarının günümüzde varlığını devam ettirdiği bilinmektedir ${ }^{18}$.

14. yüzyılda birçok toplumda dışlanan ve tanrının cezalandırdığı insanlar olarak tiksinti ile bakılan cüzamlı hastalar için Dulkadiroğulları tarafından Kayseri’de özel bir ihtisas hastanesi kurulmuştur. Bu hastane de sadece cüzam hastalarının tedavi edildiği bilinmektedir. Günümüz yeri kesin olarak bilinmeyen hastane sadece Kayseri'ye hizmet etmemiş, çevre beylik ve topluluklardan da gelenler burada tedavi olmuşlardır ${ }^{19}$.

Selçuklular zamanında tıp, tıp kurumları ve teşkilâtı önemli bir gelişme kaydetmişti. Bu dönemde yolcu ve tüccarlara hizmet veren Karatay kervansarayı ile Kütahya'daki Germiyan oğlu Yakup Bey'in imaretine ait vakfiyeler, bu müesseselere gelen veya orada iken hastalığa tutulan yolcuların iyileşinceye kadar bunların hastanelerinde karşılıksız tedavi edilmelerini sağlamaktaydılar ${ }^{20}$. Bu dönemde şöhret kazanan Yakup Bey'in hekimi Şeyhi Sinan b. Mecdüddin'i de burada yad etmek gerekir. Şeyhi-i kadim olarak Türk edebiyat tarihinde şiirleri ile meşhur olan bu hekim, Germiyan oğullarına yapmış olduğu büyük hizmetlerden sonra Osmanlıların hizmetine girmiş ve bu dönemde Re'îsu'l-Etibbâ' (Tabipler Başkanı) görevini üstlenmiştir. Şeyhî, Emîr Süleyman, Çelebi Mehmet ve II. Murad'ın hizmetinde bulunmuş, onların övgülerine mazhar olmuş ve bir rivayete göre Çelebi Mehmet'in sinirlilik hastalığını tedavi etmiştir. Tıp sanatını bulunduğu mekânla İran'da öğrenmiş olan Sinan, şairliği yanında bilgili ve kabiliyetli bir göz hekimi idi. Hayatının sonlarına doğru Kütahya'da bir aktar dükkânı açarak sanatını devam ettirmeye çalışmış ve muhtemelen 832 (1428) yılından sonra da burada vefat etmiştir. Tasavvuf şiirlerine de yer verilen ve 1700 beyitten meydana gelen bir şiir divanı bulunmaktadır. Bu ünlü hekim, divanı dışında şu eserleri de kaleme almıştır: Dürerü'l-Akâ'id (Kelâm ilmi ile ilgilidir), Nizâmî'nin Hüsrev şiirinin Tercümesi (bu şiirin bir kısmını çevirmiştir), Harnâme, (124 beyitten oluşan lirik şiirler) ${ }^{21}$.

Germiyanoğullarında Germiyanoğlu Yakub Bey tarafindan bir imaret inşa edilmiş olup, Türkçe vakfiyesindeki "ve dahi anda kim haste olası olursa, ana hekim getüreler, 'ilâc itdüreler ve hekim hakkını vireler ve edviye bahâsın vireler"22 denilmektedir. Bu durum Germiyanoğullarında sağlik hizmetlerinin bedelsiz olarak, diline dinine ve rrkına bakılmaksızın herkes için müsavi şekilde uygulandığını ifade etmektedir ${ }^{23}$.

Aydınoğulları Beyliği döneminde ilim ve fikir adamlarına karşı çok koruyucu ve ödüllendirici bir politikanın uygulandığı bilinmektedir. Özellikle hekimlere büyük saygı göstermişlerdi. Arap gezgini İbn Battuta, Aydınoğlu Mehmed Bey'i ziyareti sırasında, saraya gelen Yahudi hekimin selamına kadı ve müderrisin ayağa kalkarak karşılık verdiğini, hekimin sultanın önündeki sedire oturduğunu kaydetmiştir ${ }^{24}$.

Beylikler döneminin önemli tedavi merkezlerinden birisi de kaplıca ve 1lıcalardır. Bu şifa kaynağı sular Beylikler döneminde halkın kullanımına açılmış ve çevresinde sosyal tesisler inşa edilmişti. İbn Batuta, Bursa'ya geldiğinde şehrin yakınında bir kaplıcanın var olduğunu ve bu

\footnotetext{
${ }^{17}$ Ali Haydar Bayat, Tıp Tarihi, s. 273-4.

18 K. İsmail Gürkan, "Selçuklu Hastaneleri”, Malazgirt Armăganı, TTK yay., Ankara, 1993, s. 45.

${ }^{19}$ Süheyl Ünver, “Anadolu Selçuklularında Sağlık Hizmetleri”, Malazgirt Armă̆anı, s. 15.

${ }^{20}$ Osman Turan, Türkiye Selçukluları Hakkında Resmî Vesikalar, s. 52.

${ }^{21}$ Bkz. A. Süheyl Ünver, Selçuk Tababeti XI-XIV üncü Asırlar, s. 110-111.

${ }^{22}$ Ali Haydar Bayat, Tip Tarihi, s. 292.

${ }^{23}$ Aynı eser, Tip Tarihi, s. 292.

24 Aynı eser, Tip Tarihi, s. 292; İbn Batuta, Tuhfetu'n-Nüzzâr fi Garâibi'l-Emsâr ve Acâibi'l-Esfâr, Beyrut, (Tarihsiz), I, s. 232.
} 
kaplıcada tedavi görmek için çok uzaklardan hastaların geldiğini anlatmakta ve gelen hastaların üç gün boyunca ücretsiz misafir edildiğini anlatmaktadır ${ }^{25}$. Beylikler döneminde Selçuklulardan kalma birçok kaplıca onarılarak hizmet vermeye devam etmiş, ayrıca Anadolu'nun farklı yerlerinde sıcak su kaynakları üzerine sosyal tesisler oluşturulmuştur.

\section{Erken Osmanlı Döneminde Tıp Çalışmaları}

\section{A. Erken Osmanlı Döneminde Sağlık Kurumları}

1326 tarihinde Osmanlılar tarafından fethi gerçekleştirilen Bursa da yoğun bir imar faaliyetine girişilmiştir. Bu dönemde Osmanlı hükümdarlarından Yıldırım Bayezid Dâru't-T1bb adlı büyük bir külliye kurmuştur. Bu kurum görevini birkaç yüzyıl boyunca devam ettirmiş ve bölgenin önemli bir sağlık merkezi olmuştu. Sağlık hizmetlerinin yanında tabiplerin yetiştirildiği bir kurum olduğu da bilinmektedir. Bursa'nın batısında Uludağ'ın ovaya doğru inen zümrüt renkli eteklerinde, havadar ve geniş bir arazide inşa edilen Dâru't-Tıbb, Türk mimarlığının eski stiline göre inşa edilmiş ve Anadolu'da yapılan hanlar tarzında, iki kattan oluşuyordu. Ayrıca ortasında da geniş bir bahçesi vardı. Buranın ağlık hizmetlerinin yanında tabiplerin yetiştirildiği bir kurum olduğu da bilinmektedir ${ }^{26}$. Ramazan 802/Mayıs 1400 tarihli vakfiyesinden anlaşıldığı kadarıyla dâruşşifâda bir başhekim, iki hekim, iki eczacı, iki şerbetçi, birer aşçı ve ekmekçiden oluşan personel bulunmaktaydı. Ramazan 802/Mayıs 1400 tarihli vakfiyeye göre personelin durumu ve aylık maaşları şöyle idi:

1. Bu dârüşşifâ' da çalışan başhekime, günlük 12 gümüş dirhem, y1llık 20 müd $^{27}$ buğday, 4 müd pirinç.

2. 2 adet hekimden, her birine 8 dirhem gümüş, 15 müd buğday, 2 müd pirinç.

3. 2 adet şerbetçiden her birine 2 gümüş dirhem, 12 müd buğday.

4. 2 adet eczacıdan her birine 2 gümüş dirhem, 12 müd buğday.

5.1 adet aşçıya 2 gümüş dirhem, 12 müd buğday.

6. 1 adet ekmekçiye ise 2 gümüş dirhem, 12 müd buğday.

Ayrıca bu darüşşifa Osmanlı Türklerinin beylikten devlete geçiş sürecinde eğitim politikasını belirleyen bir kuruluş olmuştur. Medrese ile darüşşifanın yan yana inşa edilmesi teorik ve pratik uygulamaların aynı anda verildiğinin göstergesi kabul edilebilir ${ }^{28}$. Bundan başka, her gün hastaların yiyecek ve içeceklerini ve diğer ihtiyaçlarını karşılamak üzere 260 dirhem gümüş, her gün dörtte bir kile ${ }^{29}$ pirinç ve yeteri kadar da buğday tahsis edilmişti ${ }^{30}$.

\footnotetext{
25 İbn Batuta, s. 236.

${ }^{26}$ G. Çantay, "Bursa'da Osmanlıların İlk Tıp Kurumu”, Erdem, IX (1996), s. 499-504.

${ }^{27}$ İbn Abdilhakem'in kroniğinden (VII. yüzyıl) bilgi aktaran el-Makrizî, o çağda Mısır'da 6 müdd'ün 1 vayba olduğunu bildirir. Vayba'yı tam ve kesin bir şekilde 15 litre olarak hesaplayabildiğimize göre, İslam'ın ilk yıllarında Mısır'da kullanılan müdd için 2,5 litrelik değer elde ediyoruz. Daha sonraki yıllar için Mısır'daki müdd hakkında kayıt yoktur. Bkz. Walther Hınz, İslam'da Ölçü Sistemleri, (Çev. Acar Sevim), İstanbul, 1990, s. 56. Aslında müdd; 400 kilogram bir ağırlığa eşdeğerdir.

28 Gönül Çantay Güreşsever, Osmanlı Türklerinde Tıp Eğitimi, Osmanlı Devletinde Sağlık Hizmetleri Sempozyumu, (Haz. Bilal Ak-Adnan Ataç), Ankara 2000, s. 125-134.

29 Arapça keyl kelimesinden türetilmiş olup mastar olarak “ölçmek”, isim olarak da "ölçek" anlamına gelmektedir. Bu haliyle de kile, ölçek demektir. Ârâmicede keylâ, Farsça'da kîle, keyle, keyli, Türkçede ise kile şeklinde kullanılmaktadır. Araplar tarafından keylece olarak kullanılan ve küçük kile anlamına gelen bu ölçü birimi, Emevî halifesi Hişâm b. Abdulmelik döneminde (724-743) kullanılmaktaydı. Kilenin 300 dirhemi aşkın bir ölçü birimi olduğu ifade edilmektedir. Oysa XIV. Yüzyılın başlarında Güney Anadolu'da kullanılan kile (ghille) müdd'ün (moggio) yirmide birine eşitti. XV. yüzyılın sonlarına gelindiğinde, İstanbul, Bursa, Aydın,
} 
Ortaçağ Avrupa'sında ruh hastalarının hasta olarak kabul edilmediği, şeytanın içine girdiği düşüncesi ile eziyet ve işkenceler yapılan, hatta bazıları yakılarak öldürüldüğü dönemde, Türkler onları birer hasta olarak kabul etmiş; ruh sağlığına, ruh hastalarına ve tedavilerine büyük önem vermişlerdir. Ruh hastalıklarının müzikle tedavisini ilk defa düzenli ve bilinçli bir biçimde uygulayan ve bu tedavinin öncülügünü yapanlar Türkler olmuştur ${ }^{31}$. Beylikler döneminde akıl hastalıklarının tedavisinde müzikle tedavi uygulayan hastane bölümleri oluşturulduğu görülmektedir. Bunlardan en önemlileri Kayseri Gevher Nesibe Tıp Medresesi ve Maristan1, Divriği Turan Melik Darüşşifas1 ve Amasya Darüşşifasını saya biliriz. Kayseri Gevher Nesibe Tıp Medresesi ve Maristanı Darüşşifada, ruh hastaları için 18 odadan meydana gelen Bimarhane bulunmakta idi Amasya Darüşşifasının müzik ve su sesiyle tedavide Anadolu'da önemli bir namının olduğu bilinmektedir. Darüşşifanın en önemli özelliği; dünyada akıl hastalıklarının müzik ve su sesiyle iyileştirildiği ilk yer olmasıdır. Ses titreşimlerinin doğrudan beyin dokularına etki ettiği düşüncesi, ruh hastaları üzerinde müzikle tedavi uygulanmasını sağlamıştır ${ }^{32}$.

Osmanlı dönemi tıp tarihi araştırmalarında büyük emeği geçen Prof. Dr. A. Süheyl Ünver'in şu satırlarına kulak verelim;

“... Selçuklular zamanında tıp kitapları çok defa Arap ve bazen de Fars dillerinde yazıll idi. Lâkin Osmanlılarda ilim dili olarak Türkçe başa geçmişti. Bu sebeple XIV. Asırdan itibaren Arapça tıp eserlerinin Türkçeye tercüme edilmesine, hatta Türkçe teliflere de başlanmıştır. Meselâ 792 (1389) da Gerede'de Artık dağında dinlenirken Geredeli İshak b. Murad’33 ${ }^{\text {in }}$ (Havassül Edviye) ismiyle yazdlğı Türkçe eser sade ve güzel Türk dili bakımından ve Türkçe ile bütün ilaçların Türkçe mukabillerini vermesi dolayıslyla çok kaymetlidir. Ístanbul'da Topkapı sarayında Hazine K. N. 1693 de ve Ali Emiri K. N. 109 da kayıtlı birer nüshası vardır. Eserde tıp müfredatı alfabetik olarak tertiplendiği gibi, bunların hangi hastalıklara iyi geldiği ve daha birçok tıbbî ve sıhhî bilgiler vardır. Çelebi Sultan Mehmet adına Türkçe yazılan müntahap eseri de bu devrin en mühim tıbbî ve ispençiyarî meahzlerindendir. Buna benzer tıbb̂̂ yazma kitaplar İstanbul kütüphanelerinde az değildir. Âlimleri bu hususa teşvik edenler arasında iki büyük simayl, Aydınoğullar ile Timurtaş Paşazade Gazi Umur Beyi hürmetle anmak lâzımdır. Filhakika onlar sayesinde birçok eserler dilimize çevrilmiştir ki Müfredatı Ibni Baytar ${ }^{34}$

Erzurum ve Menteşe kilesi 1/20 müdlük (4 şiniklik) bir hacme tekabül etmekteydi. Bkz. Cengiz Kallek, T. D. V. İslam Ansiklopedisi, Kile Maddesi, Ankara, 2002, c. XXV, s. 568.

${ }^{30}$ Osman Şevki, s. 88. Ayrıca bkz. Hüseyin Kayhan, "Beylikler Devrinde Tıp Bilimi ve Hekimler", History Studies, Volme 2/3 2010, s. 225.

${ }^{31}$ M. Erkan, S. Şahin, “Türklerde Müzikle Ruh ve Sinir Hastalıklarının Tedavisi”, Kayseri Üniversitesi Gevher Nesibe Bilim Haftası ve Tip Günleri, Kayseri 11-13 Mart 1982; s. 572-579.

${ }^{32}$ Sezer Erer-Elif Atıcı, “Selçuklu ve Osmanlılarda Müzikle Tedavi Yapılan Hastaneler”, Uludă̆ Üniversitesi Tıp Fakültesi Dergisi, 36 (1), Bursa 2010, s. 29-32.

33 Anadolu Beyliklerinden Lâdik Beyliğinin son beyi olan İshak Bey, ilme düşkünlüğü ve ilim adamlarını koruması ile tanınan ve kendisi de eser bırakmış olan bir Türk büyügüüdü. 1389 tarihinde, Gerede'deki Argıt Dağı'nı gezerek orada bulunan otları tespit edip, hangi hastalıkların iyileştirilmesi için, nasıl kullanılması gerektiğine dair kaleme aldığı Muntehab-i Şifâ-i Tip, diğer ismi Edviye-i Mufrede adlı eseri Beylikler döneminde bu alanda yazılmış olan ilk eser olma özelliğini taşımaktadır. Bkz. İsmail Hakkı Uzunçarşılı, s. 212. Ayrıca bkz. Mustafa Canpolat, "XIV. Yüzyılda Yazılmış Değerli Bir Tıp Eseri Edviye-i Müfrede”, Türkoloji Dergisi, V, 1979, s. 21-49. Ayrıca bkz. Mustafa Canpolat-Zafer Önler, Edviye-i Müfrede, Türk Dil Kurumu Yayınları, Ankara, 2007.

34 Aydınoğullarından Umur Bey'in emriyle kaleme alınmış, müellifi bilinmeyen, güzel ve sade Türkçesi bakımından dikkati çeken bir kitaptır. Eser, Ortaçă̆'ın en büyük botanikçi ve eczacısı olan İbn Baytar'ın Arapça eserinin Aydınoğlu Umur Bey adına yapılmış bir çevirisidir. Bkz. İlter Uzel, Kenan Süveren, "İlk Türkçe Tıp Yazmalarına Genel Bir Bakış", Tıp Tarihi Araştırmaları, Sayı 2, İstanbul, 1988, s. 131. Timurtaş oğlu Umur 
ISSN-2199-353X

Online only at http://www.cahij.com/

tercümesi bunlardan biridir. Hastanelerden başka Osmanlı Türkleri, Selçukluları örnek alarak bazı tedavi ve istirahat yurtları ve tecrithaneler kurmuşlard. Selçuklular zamanında Sivas'ta yapılan Dârürrâhe, Saruhanlıların Manisa'daki Körhaneleri, Nihayet Osmanlılardan İkinci Murad'in 825-855 (1421-1451) Edirne'de Kirişhane semtinde yaptığı Leprozeri (Cüzamlılar yurdu) buna misal olarak iftiharla gösterilir ki bu tarihlerde Avrupa'da benzerleri yoktur." ${ }^{35}$.

\section{B. Erken Osmanlı Döneminde Tabipler ve Eserleri}

Erken Osmanlı döneminde sağlık kurumlarında meydana gelen gelişmelerin bir benzerini de tıp ve eczacılıkla ilgili yazılan eserlerin yazımında görüyoruz. Bu dönemde Cemaleddin Aksaray-i, Hâlu'lMu'cez adında bir eser, Anadolu'nun İbn Sina'sı olarak ün kazanan Hacı Paşa, Müntahabü'ş-Şifâ (1408) ve Teshilü'ş-Şifâ (1408) adında iki eser kaleme almışlardır. Dönemin en meşhur hekim ve cerrahı olan Amasyalı Şerefeddin Sabuncuoğlu ise Akrabadin (1453) olarak adlandırılan resimli ilk Türkçe tıp kitabını kaleme almıştır. Osmanlı tabip ve yazarları bununla da kalmayarak bu dönemde yaklaşık 10 eser daha yazmışlardır. Bu eserleri şöyle sıralamak mümkündür:

1. Eşref b. Muhammed, Hazâinü's-Sa 'âdât (XV. yüzyılın baş1).

2. Ahmedî, Tervihu'l-Ervâh (1403-1410).

3. Ahmed Dâ' ${ }^{36}$, Tıbb-ı Nebevî Tercümesi ${ }^{37}$ (1413).

4. İbn Şerif, Yadigâr (1413).

5. Hayreddin Bican, Hülâsatü't-Tıbb ${ }^{38}$, (XV. yüzyılın ilk yarısı).

6. Abdulvehhab, Müntehab (1420).

7. Şirvanlı Mahmud, Kemaliye $e^{39}$ (XV: yüzyılın ilk yarıs1).

Bey’in isteği üzerine yapılan Kâmilü’s-Sınâ'a Tercümesi de önemlidir. Bu eser, Ali bin Abbas bin el-Mecusî tarafından yazılmış olan Kâmilü's-Sınâ'ati’t-Tıbbiye (yahut Kitâbü'l-Melikî) adlı eserin bazı bölümlerinin Türkçeye tercümesidir. Bkz. Ahmet Atillâ, Kartal Şentürk, Eski Türk Edebiyatı Tarihi, Dergâh Yayınları, Ankara, 2007, s. 63.

${ }^{35}$ A. Süheyl Ünver, Osmanlı Türklerinde Hekimlik ve Eczacılık, İstanbul, 1952, s. 30.

${ }^{36}$ Tam adı Ahmed b. İbrahim b. Mehmed olup Adı ve mahlası ile birlikte Ahmed-i Dâ’i olarak tanınmaktadır. Germiyan'da doğduğu bildirilmektedir. Ancak doğum tarihi hakkında verilen bilgiler çelişkilidir. I. Murad devri şairlerinden olan bu zat, Germiyan'da bir müddet kadılık yapmıştır. Süleyman Şah'ın 1387 yılında vefatından sonra II. Yakub'un himayesine girmiş; ancak Germiyan toprakları Osmanlı ülkesine katılması sonucunda Kütahya'daki Emir Süleyman'ın yanına gitmiştir. Şairimiz, 808'de (1406) Çengnâme adlı mesnevisini Emîr Süleyman adına kaleme almıştır. 1410 yılında Emîr Süleyman'ın öldürülmesi üzerine anılan şair, Çelebî Mehmed'in himayesine girdi. Bir süre sonra da Çelebî Mehmed'in oğlu Murad'ın hocası olarak görevlendirildi. Çelebî Mehmed'in 1421 yılında vefatından sonra Mehmed-i Dâ'î, II. Murad'ın koruması altına alındı. Vefat tarihi bilinmeyen şairin Bursa'da adı ile anılan bir cami, bir mahalle ve bir hamam bulunmaktadır. Mezarının bu şehirde olduğu söylenmektedir. Eserlerini şöyle sıralamak mümkündür: 1. Tercüme-i Tefsîr-i Ebi'l-Leys esSemerkandî 2.Miftâhu'l-Cenne 3. Teceme-i Kitâbü't-Ta'bîrnâme 4. Tercüme-i Eşkâl-i Nâsîr-i Tûsî 5. Teressül 6. Tercüme-i Tezkiretü'l-Evliyâ 7. Tercüme-i Tıbb-i Nebevî 8. Vesîletü'l-Mülûk fi Ehli's-Sülûk 9. Farsça Dîvân 10. 'Ukûdu'l-Cevâhir 11. Camasbnâme 12. Tükçe Dîvân 13. Vasyyet-i Nûşirevân-1 Âdil be-Pusereş Hürmüz-i Tâcdâr 14. Çengnâme. Geniş bilgi için bk. Günay Kut, T. D. V. İslam Ansiklopedisi, Ahmed-i Dâ'î Maddesi, İstanbul, 1989, c. II, s. 57.

$37 \mathrm{Bu}$ eser, Timurtaş Paşaoğlu Umur Bey’in isteği üzerine, Ebu Nu'aym el-İsfahanı̂’nin Tıbb-ı Nebevî adlı eserinin Ahmed b. Yusuf et-Tifâşî tarafından yapılan muhtasarının çevirisidir. Şimdiye kadar tespit edilen dört nüshasından biri İstanbul Üniversitesi Tıp Tari Kütüphanesi'ndedir. (nr. 90). Bkz. Aynı eser, c. II, s. 57.

${ }^{38}$ Eser Hekim Hayreddin'in tarafından Hulâsatu't-Tıbb adıyla, Candaroğluları'ndan İsfendiyar Beyzade Kasım Bey adına yazılmış toplama bir eserdir. Eserin yazılış tarihi tam bilinmemekle birlikte, XV. yüzyılın ortalarında yazıldığı tahmin edilmektedir. Hekim Hayreddin, herkesin faydalanabilmesi için bu eseri Türkçe olarak kaleme aldığını, Esbâb ve Alâmet, Zübde fi’t Tibb, Zahire-i Harzemşahî ve el-Mansub ve'l-Merfu adlı dört kitaptan faydalanarak yazdığını belirtir. Bkz. Berna Arda, "Hekim Hayreddin'in Hulâsa Eseri”, Erdem Dergisi, AKM Yayınları, Cilt:12, Sayı: 34, TTK Basımevi, Ankara, Mayıs 1999, s. 17-26. 
ISSN-2199-353X

Online only at http://www.cahij.com/

\author{
8. Mümin b. Mukbil, Zahîre-i Muradiye (1437). \\ 9. Akşemseddin ${ }^{40}$, Mâidetü̈ 'l-Hayât ${ }^{41}$ (XV. yüzyılın ortas1). \\ 10. Akşemseddin, Risâletün fi't-Tibb $(1453)^{42}$.
}

Anılan yazarlardan Cemaleddin Aksaray-i, Murat Hüdavendigar döneminde yetişmiş; hadis, tefsir, fikıh, ahlak, edebiyat ve tıp dallarında eserler vermiş, Aksaray-i nisbesinden dolayı Aksaraylı olarak kabul edilen ancak Tebriz-i nisbesinden dolayı da Tebriz'de doğmuş olabileceği varsayılan âlim bir insandır. İlk tahsilini Aksaray'da tamamlamış, Amasya'da devam etmiş ve Amasya Kadılığı ve Kazaskerliği yapmış, oradan Konya kadılığına atanmış, buradan da Aksaray Zincirli medresesine atanarak önemli derecelerde talebeler yetiştirmiştir. Eserlerini devrin geleneğine uyarak Arapça yazmış, bazı eserlerini ise Farsça ve Türkçe olarak yazmıştır. Fahreddin Razi ekolünün Anadolu'ya taşıyıcısı ve en önemli müessislerinden olan Cemaleddin Aksaray-i, Osmanlı Devletine kendi sülalesi ile birlikte, pek çok ilim ve devlet adamı yetiştirecek bir kadronun ilk simasıdır. Kâtip Çelebi, Cemaleddin-i Tebrizi-Aksray-i'nin 740 senesinde 26 yaşında olduğunu söylemektedir. Buna göre Cemaleddin-i Aksarayi'nin 714/1313-14 senesinde doğduğunu söyleyebiliriz. Bu kayıt Cemaleddin-i Aksarayi'nin Tebriz'den Aksaray'a geldiği fikrini, yani Tebriz'li olabileceğini de ifade etmektedir. Kaynaklar Alaeddin Esved (Ö. 800/1397)'in İran'da yüksek tahsil yaptı̆̆ında hemfikirdirler. Bursal1, Esved'in Cemaleddin Aksaray-i'den yararlandığını söylemektedir. Bu da Aksaray-i'nin Tebriz'den geldiği fikrini vermektedir. Ancak Aksaray-i'nin Anadolu'da Tebrizi nisbesi ile kaydına ender rastlanır. Ancak, Aksaray-i nisbesi, onun Aksaray'lı olduğunu tespite yeterli gelmektedir. Zincirli Medresesinde müderrislik yapmıştır ${ }^{43}$. Eseri Hâlu'l-Mu'cez, İbni Sînâ'nın Kânûn'unun İbnu'n-Nefîs tarafından

\footnotetext{
${ }^{39}$ Ferhat Kurban, Mahmud Şirvanî, Sultaniyye (Giriş- Metin- Sözlük), İstanbul Üniversitesi, Sosyal Bilimler Enstitüsü, (Yayınlanmamış Yüksek Lisans Tezi), İstanbul, 1990, s. III-IV.

40 Tam adı Şemseddin Muhammed b. Hamza'dır. Babası, Şeyh Şehâbeddin Sühreverdî'nin torunu olup nesebi Hz. Ebu Bekir'e dayanmaktadır. Akşemseddin veya Akşeyh olarak tanınır. H. 792 (M. 1390) yılında Şam’da doğmuş ve yedi yaşında babasıyla birlikte Anadolu'ya gelerek Amasya'ya bağlı Kavak ilçesine yerleşmiştir. Dinî ve iyi bir tıp gördükten sonra Osmancık Medresesi'ne müderris olarak tayin edildi. Yirmi beş yaşında Fars ve Mâverâünnehr bölgesine yolculuk yaptı; arkasından Haleb'e gitti. Fakat burada uzun süre kalmayarak Ankara'ya döndü. Hacı Bayrâm-ı Velî'nin vefatından sonra onun yerine irşâd makamına geçti. Akşemseddin'in tıp alanında şöhreti, II. Murad'ın kazaskeri Çamdarlıŏlu Süleyman Çelebî ve Fâtih Sultan Mehmet'in kullarından birini tedavi ederek iyileştirmesiyle yaygınlık kazanmıştır. Bu başarılı tedavi sonucunda Fâtih'in kızı, ona Beypazarı'ndaki pirinç mezralarını vermiştir. İstanbul'un fethinden sonra Ayasofya'da kılınan ilk Cuma namazında hutbeyi Akşemseddin okumuştur. Ünlü sahabi Ebâ Eyyûb el-Ensârî'nin kabrinin Fâtih Sultan Mehmet'in buyruğuyla anılan âlim tarafından ortaya çıkarıldığı söylenmektedir. Akşemseddin hayatının son günlerini Göynük’te geçirdi ve Şubat 1459 yılında burada vefat etti. Akşemseddin'in, devrinin iyi ve becerikli bir tabibi olduğu anlaşılmaktadır. Ayrıca tıp tarikinde ilk defa mikrop meselesini ortaya atmak ve hastalıkların bu yolla bulaştığı düşüncesini öne süren ve İtalyan hekim Fracastor'den en az yüz yıl önce bu konuya ilk temas eden tabip olduğu ileri sürülmektedir. Eserlerini şöyle sıralamak mümkündür: Risâletü'n-Nûriyye (Tasavvuf), Def'u metâ'ini's-Sûfiyye (Tasavvuf), Risâle-i Zikrullâh (Tasavvuf), Risâle-i Şerh-i Akvâl-i Hacı Bayrâm-1 Velî (Tasavvuf), Risâle fi Devrâni's-Sûfiyye (Tasavvuf), Nasîhatnâme-i Akşemseddin (şiir divanı), Mâdetü’l-Hayât (Tıp). Bkz. Orhan F. Köprülü-Mustafa Uzun, T. D. V. Íslam Ansiklopedisi, Akşemseddîn Maddesi, İstanbul, 1989 , c. II, s. 199-302.

$41 \mathrm{Bu}$ eserin ona ait olup olmadığı tartışmalı olmakla birlikte araştırmacıların büyük bir kısmı bunun Akşemseddin tarafından kaleme alındığını kabul etmektedir. Eserin geç tarihlerde istinsah edilmiş birçok nüshası bulunmaktadır. En eski tarihi nüsha, 1096 (1685) yılında istinsah edilen Ali Emîrî yazmasıdır. Esere ait diğer nüshaların, Türkiye Kütüphaneleri İslâmî Tıp Yazmaları Kataloğunun 139 sayfasında yer aldığı bildirilmektedir. Bkz. Ayn1 eser, c. II, s. 301.

42 Bkz. Cevat Yalın, “15. Yüzyılda Osmanlılarda Kulak Hastalıkları Tedavi ve Cerrahisi”, I. Türk Tıp tarihi Kongresi, Kongreye Sunulan Bildiriler, İstanbul, 17-19 Şubat 1988, Ankara, 1992, s. 103-104.

${ }^{43}$ www.aksaray.gov.tr.
} 
Mu'cezu'l-Kânûn adlıyla yapılan özetinin açıklanmasını ihtiva etmektedir 1388 yılında yine orada vefat etmişsirir ${ }^{44}$.

Beylikler döneminin 14. Yüzyılına damgasını vuran Celâleddîn Hızır b. Hoca Ali el-Konevî (Hacı Paşa), Şair Ahmedî, Molla Fenarî ve Bedreddin Simâvî ile birlikte tahsil yapmış ve Kahire'deki Kalavun hastanesinde başhekim olarak görev almıştır. Kahire'de çalışkanlığı ve zekâsıyla başarılı bir öğrencilik hayatı geçirmiştir. Aslında bu hekim, öğrenciliği esnasında ağır bir hastalık yakalanmasından dolayı tıbba ilgi duymuş, bu alanda da kendini yetiştirmiştir ${ }^{45}$. Hacı Paşa, Aydınoğlu Mehmed Bey'in daveti üzerine memleketine dönmüş ve Ayasluk ve Birge'de çalışmaya başlamıştır. Burada kendisine tevdi edilen kadılık görevi yanı sıra Aydınoğlu sarayının hekimliğini de yürütmüştür. Kaleme aldığ 1 eserlerinde Calinos (Galenos) ve İbn Sina'ya paralel bir çizgide hareket etmekle beraber kişisel görüş ve tespitlerini de aktarmıştır. Eserlerinde bilgileri Arapça ve Türkçe olarak açık seçik bir şekilde sunan Hacı Paşa gereksiz detaydan kaçınmıştır. Yukarıda belirtilen iki eseri dışında Bevâsir ve İhtilaçnâme adında iki eser daha kaleme almıştır ${ }^{46} .1380$ yılında Aydınoğlu İsa Bey'in adına Şifâü'lEskam adlı eseri yazmıştır ${ }^{47}$. Yazdığı bu eseri üç bölüme ayırmış olup, birinci kısımda genel olarak tıp biliminden; ikinci kısmında yiyecek, içecek ve ilaçlardan; üçüncü kısmında da hastalıklardan, bunların sebepleri, belirtileri ve tedavilerinden bahsedilmektedir. Onun yine tıp konusunda Arapça ve Türkçe olarak yazmış olduğu başka eserler de vardır. Kitâbu't-Tâlim eski hekimler ve kendi devrindeki hekimlerden faydalanarak yazdı̆̆ı, Şifâu'l-Eskâm'a benzeyen Arapça bir eserdir. Son bölümünde tıp etiğinden bahsederek, hekimliğin ahlaki yanından bahseder ${ }^{48}$. Müellifin diğer bir Arapça eseri Kitâbu'sSaade ve'l-ìkbâl Muretteb alâ Erbaa Akvâl adlı eseri olup, coğrafi özelliklerin ve iklimin sağlığa tesirleri, nabız, idrar, kan alma vs. gibi konulardan bahseder. Bu eser Muntehabu'ş-Şifâ adıyla Türkçeye çevrilmiştir. Ölüm tarihi ile ilgili iki farklı tarih verilmiş olup 1424'te Birgi veya 1417 Kahire'de vefat ettiği belirtilmektedir. Birgide öldüğünü ve mezarının burada bulunduğu iddia edenler. 1935 'te mezarının bulunduğu yere mermer bir anıt yapılmıştır ${ }^{49}$.

Şerefeddin Sabuncuoğlu ise 1386 yılında Amasya'da doğmuş ve bu şehrin Darüşşifası'nda çalışmış ve 1465 yılında ünlü Endülüslü tabip Ebu'l-Kâsım ez-Zehrâvî'nin et-Tasrif li men Aceze ani 't$T e^{\prime} l i f f$ adlı eserinin küçük cerrahiye ait olan kısmını Türkçeye çevirmiştir. Şerefeddin Sabuncuoğlu, anılan eseri çevirmekle kalmamış, kişisel tespitlerini, geliştirdiği cerrahî aletleri ve bizzat yapmış olduğu ameliyat ve operasyonların resimlerini ekleyerek Cerrahiyyetü'l-Hâniye adlı eseri kaleme almıştır. 1477 yılında yazılan ve onun kendi kişisel tecrübelerini kapsayan Mücerrebnâme adında diğer bir eseri de bulunmaktadır. Burada horoz ve kendi bedeni üzerinde denediği yılan zehrine karşı bir nevi tiryak hakkında da bilgi vermektedir ${ }^{50}$.

Ahmedî mahlası ile tanınan yazarın tam adı Tacüddin İbrahim b. Hızır'dır. Döneminin seçkin âlimlerinden biri olan Ahmedî'nin 1334 y1lında Kütahya'da doğduğu zannedilmektedir. Ancak 735/1334-815/1412-3 yılları arasında yaşamış olan bu şair tabip, net olmamakla birlikte muhtemelen Amasya şehrinde doğmuştur. Kesin olarak doğum yeri bilinmediği gibi, ilk tahsilini de nerede ve nasıl yaptığı da bilinmemektedir. Fakat Tezkire yazarları ve araştırmacılar, Ahmedî'nin, bilgisini artırmak ve öğrenimini tamamlamak için Mısır'a gittiği, orada müderris Ekmelüddin el-Bâbârtî (ö. 1384)'den ders aldığı, İslâmî ilimlerden başka tıp ve geometri sahalarında da esaslı bilgiler edindiği konusunda

\footnotetext{
${ }^{44}$ A. A. Adıvar, Osmanlı Türklerinde İlim, İstanbul, 1982, s. 25.

${ }^{45}$ Ali Haydar Bayat, Tip Tarihi, s. 283.

${ }^{46}$ Bkz. Emine Atabek, s. 31.

47 İsmail Hakkı Uzunçarşı1lı, s. 212.

48 Aynı eser, s. 212.

${ }^{49}$ Ali Haydar Bayat, Tip Tarihi, s. 283.

${ }^{50}$ Emine Atabek, s. 31.
} 
hemfikirdirler. Aynı zamanda bu âlimin "Devrinin şâir-i pür-ma'ârifi”" unvanını alarak Anadolu'ya döndügünü de ifade etmektedirler ${ }^{51}$. Âlimimiz Anadolu'da önce Germiyan ve Aydınoğulları sarayında, özellikle de Germiyan Beyi Süleyman Şah (öl. 1387)'ın himayesinde öğretmenlik yaptı. Daha sonra da Aydın oğullarından Mehmed Bey'in küçük oğlu İsa Bey (öl. 1395)'in hizmetinde bulundu. 1390 yılından sonra Osmanlı şehzadelerinden Emir Süleyman Çelebi'nin yanına gitti. Ahmedî 815/1412-3 yılında seksen yaşındayken Amasya'da vefat etmiştir. Eserlerini şöyle sıralamak mümkündür:

1. Divân.

2. İskendernâme.

3. Dâstân-1 Tevârih-i Mülûk-i Âl-i Osmân.

4. Cemşîd u Hurşîd.

5. Tervîhu'l-Ervâh.

6. Mevlid.

7. Mirâcnâme.

8. Bedâyi'u's-Sihr fi Sanâyi'i'ş-Şi'r.

9. Mirkâtu'l-Edeb.

10. Mîzânu'l-Edeb.

11. Mi'yâru'l-Edeb.

Ahmedî'nin beşinci sırada yer alan Tervîhu'l-Ervâh adlı eseri Türkçe bir mesnevi olup teşhis, tedavi, anatomi ve pataloji konularını kapsamaktadır. 10.010 beyitten ibaret olan ve Bursa'da Çelebi Sultan Mehmed (1402-1410)'a ithaf edilen manzum eserin sonunda hijyen ve Farmakoloji ile ilgili bilgiler ihtiva etmektedir. Ayrıca eserin beşinci bölümünde çeşitli hastalıkların belirti ve tedavisine yer verilmektedir. Eserin nüshaları Bayezid Devlet Kütüphanesi Muallim Cevdet, nu. 0.47, Manisa Kütüphanesi, Muradiye, nu. 1852, Ib-253b varak, nesih, 270x170 (210x180)mm. Süleymaniye Kütüphanesi Ayasofya nu. 3595; Topkapı Sarayı Müzesi Kütüphanesi, Revan Odas1, nu. 1681 (Müellif nüshas1) ve Topkapı Sarayı Müzesi Kütüphanesi nu. 1986'da nüshaları bulunmaktadır. Eser, Bedi N. Şahsuvaroğlu tarafindan tanıtılmıştır ${ }^{52}$.

Süheyl Ünver'in bildirdiklerine göre, yukarıda adı geçen İbn Şerif'in Yadigâr adlı eseri, 1420'lerde Türkçe olarak Timurtaş Paşazade Umur Bey Çelebi adına yazılmıştır. Eserde orijinal bilgiler bulunduğu da ifade edilmektedir. Bursalı Şerif oğlunun bu kıymetli eserinden başka bir eseri olup olmadığı da belli değildir ${ }^{53}$. Bursalı hekim İbn Şerif, eserinin önsözünde şunları yazmaktadır:

"Yadigâr adlı kitabı düzdüm... Bu kitabı seferde ve hazerde bile götürmek âsândır ve mütala'a edenin muradı hâsıl olur ve ayruk kitaplara ihtiyacı olmaz ve bu kitap ehli elinde olmiyacak hiçbir tabibe muhtaç olmaz, sihhati hıfz etmek ve selâmeti def etmekle görgülü ola ve bu kitabı beş bahis eyledüm..." 54 .

\footnotetext{
${ }^{51}$ N. Sami Banarl1, Resimli Türk Edebiyatı Tarihi, İstanbul, 1971, c. I, s. 387.

52 İsmail Hakkı Uzunçarşı11, s. 212; Yılmaz Öztuna, Devletler ve Hanedanlar, Ankara, 1996, c. II, s. 75; Uludağ, Osman Şevki, Beş buçuk Asırlık Türk Tabâbeti Tarihi, (Sad. İlter Uzel), Ankara, 1988, s. 173; İlter Uzel, Kenan Süveren, "İlk Türkçe Tıp Yazmalarına Genel Bir Bakış", Tıp Tarihi Araştırmaları, Sayı 2, İstanbul, 1988, s. 133; Ali Temizel, "Ahmedî’nin Bedâyi'u's-Sihr fî Sanâyi'i'ş-Şi'r İsimli Eserindeki Türkçe ve Farsça Şiirleri”" Ahmedî’nin Farş̧̧a Eserleri-Tenkitli Metin, İnceleme, tercüme ve İndeks, (Basılmamış Doktora Tezi), Ankara Üniversitesi, Sosyal Bilimler Enstitüsü, Ankara, 2002, s. 90-98.

${ }^{53}$ Süheyl Ünver, s. 30.

${ }^{54}$ Ayn1 eser, s. 30.
} 
İbni Şerîf, yaşadığı dönemde pek çok yerde tabip bulunmadığından, tabip olmayanların da anlayacağı ve faydalanacağı tıp kitaplarına ihtiyaç olduğunu; bu sebeple kendisinin "sağlığı saklamak ve hastalıkları def etmek" amacı ile barış zamanlarında olduğu kadar, savaş zamanlarında da faydalanılacak olan bu tıp kitabını hazırladığını söyler ${ }^{55}$.

Yadigâr , beş büyük bölüm ve kısımdan meydana gelmektedir. Eser, halk sağlığı bilgileri, hastalık Semptomları, tedavi ve droglar hakkında bilgi verir; ikinci bölümün on üçüncü kısmında ise hekimlere ait öğütler yer alır. Eserin diğer bölümlerine veya genel içeriğine bakıldığında, hava, şehir, giyecek, yemekler, su, içecekler, uyku, diyet, müshil ilaçları, kan almak, kusmalara karşı alınacak önlemler, yaşlıların korunması, konukları ağırlama, hastalıkların ayırımı, ateşli hastalıklardaki tedavi yöntemleri, çeşitli müshiller, dekoksiyon, infüzyon ve hap tiplerine rastlanır. Ayrıca bu eserde içilecek ilaçlar, tiryaklar, menejit ve felç ilaçları, epilepsi hakkında bilgiler, göz hastalıkları, kulak hastalıkları, burun hastalıkları, nezle ve öksürük, nefes darlığı, pnömoni ve ilaçları, mide hastalıkları, akciğer hastalıkları, sarılık, böbrek hastalıkları, sıtma, suçiçeği ve çiçek hastalıklarına dair ilaçlar, yaralar, kırık-çıkık tedavisi hakkında da bilgiler bulunmaktadır ${ }^{56}$.

Süheyl Ünver'in bildirdiklerine göre, Umur Bey'in Türkçeye dair ve âlim Ahmed Dai'ye çevirttiği Tıbbî Nebevî adlı eseri de önemli bir kaynak niteliğindedir ${ }^{57}$.

Şirvanlı Mahmud bin Muhammed 807 (1404) y1lında Azerbaycan'ın Şirvan bölgesinde dünyaya gelmiştir. Hayatı ile ilgili fazla bilginin bulunmadığı Muhammed b. Mahmud eş-Şirvânî 14. Yüzyılın başlarında Anadolu'ya göç etmiştir. Anadolu'da Menteşe Beyi İlyas Beyin daveti ile menteşe beyliğinin himayesine giren Şirvanî saray hekimi olarak çalışmıştır. İlyas Bey'in adına ithafen İlyâsiye adlı Arapça bir tıp kitabı yazmıştır. Bu eseri sonradan yine İlyas Bey’in emriyle Türkçeye çevirmiştir ve Osmanlı dilinde birkaç tıp eseri yazmıştır. Onun en ünlü eseri, göz hastalıklarının tedavisinden bahseden Mürşid ${ }^{58}$ adlı eseridir. Bundan başka Mahmud Şirvanî Töhfeyi-Muradi kitabını yazmıştı. Değerli taşların şifaverici gücünden haber veren bu kitap Osmanlı sultanı II. Murad'a (1421-1451) ithaf edilmişti ${ }^{59}$.

Bunun yanında Çelebi Mehmed'e (1413-1421) ithaf ettiği Sultaniyye $e^{60}$ eseri de bulunmaktadır. Özellikle Mürşid, Osmanlı tıbbında göz hastalıklarına ait en hacimli eser olarak karşımıza çıkar ${ }^{61}$.

Erken Osmanlı döneminde tıpla ilgili yazılan eserler arasında Mümin b. Mukbil tarafından Sultan II Murad adına kaleme alınan ve üç kitap şeklinde hazırlanan Zahire-i Muradiye adlı eserin ayrı bir yeri vardır. Bu eser bir göz doktoru tarafından yazılmış olup birçok hastalığın tedavisi konusunda bilgiler ihtiva etmektedir. Esin Kâhya, bu eserin içeriği ile ilgili şunları yazmaktadır:

"Mümin b. Mukbil... Eserini üç kitap şeklinde hazırladığını ifade ettikten sonra, birinci kitabında, Kitab-ı Harezmşahî'den farklı olarak, anatomi ile ilgili bilgi vermez. Burada birinci makalede beyin hastalıkları, ikinci makalede baş ăgrıları ve çeşitli göz ağrıları, üçüncü

\footnotetext{
55 Bkz. Ayten Altıntaş ve Arkadaşları, Yâdigâr (Tabîb İbn-i Şerîf), 2 Cilt, 5. Merkez Efendi Geleneksel Tip Günleri Anısına (14-22 Mayıs 2004), Yerküre Yay., İstanbul, 2004, s. 91 vd.

56 Ayşegül Demirhan Erdemir, "Uluğ Bey Döneminde (15.YY) Osmanlı Tıbbından Bir Örnek: İbn Şerif'in Yâdigâr Adlı Eserinin Tiryakla İlgili Bazı Bilgiler ve Orijinal Sonuçlar”, Uluğ Bey ve Çevresi Uluslararası Sempozyumu Bildirileri, (Ankara, 30 Mayıs-1 Haziran 1994), (Yay. Haz. Songül Boybeyi), Ankara, 1996, s. 124125.

${ }^{57}$ Bkz. Süheyl Ünver, s. 30 .

${ }^{58}$ Ali Haydar Bayat, Necdet Okumuş, Necdet, Mürşid Necdet, (Göz Hastallklarl) Inceleme-Metin-Dizin-Sözlük, Atatürk Kültür Merkezi Yayınları, Ankara, 2004. s. 28.

${ }^{59}$ Ferhat Kurban, s. III-IV. Ayrıca bkz. Mustafa Argunşah, Tuhfe-i Murâdî (İnceleme-Metin-Dizin), Türk Dil

Kurumu Yayınları, Ankara, 1999, s. 96.

${ }^{60}$ Ferhat Kurban, s. IV-VIII.

${ }^{61}$ Ali Haydar Bayat, Necdet Okumuş, s. 28.
} 
makalede göz hastalıklarının tedavisi; dördüncü makalede göz kapağına arız olan hastalıklar, onların sebepleri; beşinci, altıncı, yedinci ve sekizinci makalelerde, göz tabakalarının hastalıkları ele alınmaktadır. Dokuzuncu makale kulakta görülen hastalıklarla ilgilidir. Birinci kitabın diğer makaleleri, yani onuncu, on birinci, on ikinci ve on üçüncü makaleleri ise boğaz ve göğüs organlartyla ilgilidir... Zahire-i Muradiye'nin ikinci kitabının, birinci makalesinde karaciğer ve dalak hastalıklarl; ikinci makalesinde bă̆ırsak hastalıklarl; dördüncü makalesinde genital sistem hastalıkları; beşinci makalesinde örneğin eklem ă̆rıları gibi, çeşitli ağrılar ele alınmaktadır. Aynı kitabın altıncı makalesinde ise, örneğin şişler ve yaralar gibi, çeşitli cerarahi vakalarla, cüzam, veba gibi, bazı bulaşıcı hastalıklar ele alınmıştır. Zahire-i Muradiye'nin üçüncü ve son kitabı ise, eserin diğer klsımlarına nisbetle daha kisa olup, iki makaleden meydana gelmiştir; bunlar hıfzıssihha, kan alma ve müshil gibi genel tedavi yöntemleri diye adlandırabileceğimiz bazı konularda bize bilgi vermektedir. " ${ }^{\text {. }}$.

Mümin bin Mukbil tarafindan 1437'de yazılmış olan Zahire-i Muradiyye, Zeyneddin bin İsmail Cürcânî'nin, Zahire-i Harzemşahı̂'sinin Türkçeye çevrilmiş şeklidir. Sinoplu Mukbil-zâde Mu'min'in İkinci eseri, Anatomi, hijyan ve göz hastalıkları alanında Türkçe bir eser olarak yazılan Miftâhu'n-Nûr ve Hazâ 'inu's-Surûr ${ }^{63}$ yine II. Murat'a ithaf edilmiş bir tıp derlemesidir. Kitabın ana bölümünü göz ve onunla ilgili hastalıklar, tedavi yolları, ameliyatlar oluşturur. Kitabın başında hekimlik ahlakı ve tıp eğitiminden bahsetmekte, ideal bir hekimin nasıl olması gerektiğini ayrıntılarıyla açıklamaktadır ${ }^{64}$.

Beylikler döneminde şöhret kazanan bir hekim de Kemaleddin Tebrizî'dir. Azerbaycan'da doğduğu bilinen bu hekimin doğum tarihi ile ilgili bilgi yoktur. Tebriz'de dünyaya geldiğinden dolayı Tebrizî olarak anılır. 14. Yüzyılın ilk çeyreğinde Anadolu'ya gelerek Candaroğlu İsmail Bey'in himayesine girmiştir. İlmi çalışmalarını Kastamonu'da devam ettiren Tebrizi saray tabipliği yapmıştır ${ }^{65}$.

Osmanlı tıbbının ilginç ve önemli bir yönü de, Eski Mısırlılar, Orta Asya ve Selçuklularda uygulandığı gibi, bu dönemde de mumyalamanın uygulandığına dair bilgilerin bulunmasıdır. Sezer Erer ve Elif Atıcı bu konuda şu satırlara yer vermektedirler:

“Hacı Paşa'nın on dördüncü yüzyılda yazdĭ̆ Şifâü'l-Eskâm ve Devâü'l-A'lâm adlı Arapça yazma eserinde mumyalamanın yapılışı ve kullanılan maddeler hakkında bilgiler bulunmaktadır. Bu eserde sözü edilen mumyalama yönteminin, Eski Misir'da uygulanan mumyalama yöntemlerinin on dördüncü yüzyll İslam dünyasında da devam ettiğini gösterir bir belge özelliğindedir. Hacı Paşa, mumyalama konusunu eserine ilk kez alanlardan biridir. Ünver'e göre bunun nedeni Misır'da eğitim almış olması ve bu dönemde İslam dünyasında tahnit yöntemlerinin hala devam etmekte olmasıdır... Hacı Paşa, Şifâül-Eskâm ve Devâü'l-A'lâm adlı Arapça yazma eserinde mumyalama ile ilgili olarak şunları yazmıştır: öncelikle ceset, baş aşağ iken ebucehil karpuzu ${ }^{66}$ yă̆l ve buvrak(boraks) ${ }^{67}$ sürülür. Bağırsak içeriği, lavman yapılarak,

\footnotetext{
62 Esin Kâhya, “On beşinci Yüzyılda Yaşamış bir Hekimimiz Mümin Mukbil”, I. Türk Tıp Kongresi, Kongreye Sunulan Bildiriler, İstanbul, 17-19 Şubat, 1988, Ankara, 1992, s. 96-97.

${ }^{63}$ Mehmet Bayraktar, İslam'da Bilim ve Teknoloji Tarihi, Ankara, 1985, s. 173.

${ }^{64}$ Ayn1 eser, s. 173.

65 İsmail Hakkı Uzunçarşı1lı, s. 221.

66 Karpuz cinsinden bir bitki türü olup, küçük, portakal biçiminde, sarılı yeşilli meyvesi vardır. Halk hekimliğinde, kurutulmuş meyveleri eskiden beri tedavide kullanılır. İç sürdürücü ve idrar artırıcı etkileri vardır. Afyonkeşlerde görülen kabızlığa karşı çok etkilidir. Bugün özellikle veteriner hekimlikte müshil olarak tercih edilir. Bkz. Komisyon, Büyük Larousse Sözlük ve Ansiklopedisi, c. I, s. 57.
} 
ISSN-2199-353X

Online only at http://www.cahij.com/

\begin{abstract}
kullanılan sıvı tamamen temiz çıkıncaya kadar boşaltılır. Daha sonra gül suyunda eritilen, sarısabır (aloa vera), mürr (günlük) ${ }^{68}$, akakya, râmik ${ }^{69}$ ve kâfûr ${ }^{70}$ karışımı ile bağırsaklar
\end{abstract}

${ }^{67}$ Utârid b. Muhammed el-Hâsib boraks'ı şöyle tanıtıyor: "Onun, tuz madeni gibi birçok çeşidi vardır. Bazıları akarsu gibi olup sonradan taşlaşır, diğerleri ise, özünde taş olarak bulunur. Aynı zamanda onun kırmızı, beyaz, boz vb. renklerde olanları da vardır. Bu madenden bir miktarı bir kaba konarak üzerine sirke dökülse, ateşsiz olarak kaynamaya başlar. Ayrıca o, bütün madenleri eriterek döküm için yumuşatır, böylece ateşin yakmasından koruyarak çabuk bir şekilde çözülmelerini sağlar. Yine boraks madeni eritilerek su haline getirilir de sonra içine bazı taşlar konulursa, birkaç gün zarfında ateş kullanmadan onları eritiverir. Hatta o taşlar akan su haline bile gelebilir. O yapışkan balgama karşı iyi bir ilaçtır, sıcak ve kuru bir maddedir, fakat o aynı zamanda sertliğinden dolayı, tuz gibi ishal yapıcıdır ve bazı ilaçlarla karıştırılırsa, midede oluşan gazları tedavi eder. O kalbe de iyi gelir ve bunların dışında birçok yararları bulunmaktadır.". Bkz. Abdulhalik Bakır, Ortaçağ Islam Dünyasında Madencilik ve Maden Sanayi, Ankara, 2002, s. 186.

${ }^{68}$ İslam öncesi dönemde Mekke'ye taşınan ticarî mallar arasında Güney Arabistan'ın parfümleri, çiğ baharatı, Aromalı sakızları, tütsüleri ve ilaçları önemli bir yer tutmaktaydı. Gerçekten de Hadremevt bölgesi Antikçağda en başta gelen baharat ve koku ülkesiydi. Fakat Eski Yunanlılarla Romalılar, Arabistanlıların ticaretiyle uğraştıkları bütün tüketim mallarının bizzat onların ülkelerinden çıkan yerli ürün olduğunu sanıyorlardı. Nitekim Theophrastos ve "Periplus"un yazarı, akgünlük hasadının kutsal koruma altında olan tek bir yerden yapıldığını belirttikleri gibi, Plinius da, akgünlüğün Arabistan'dan başka hiçbir bir yerde bulunmadığını ileri sürer. Oysa Somali'de bu kokulu ağacın iki türü de yetişmekteydi. Üstelik Klasik dönemde Romalı tüccarların Bâbu'lMendeb Boğazı'nın ötesindeki Afrika limanlarından yüklendiğinden dolayı “uzak iller akgünlüğü” adını verdikleri akgünlük, anılan ağaçlardan üretiliyordu. Güney Yemen ve Somali kaynaklı akgünlük, Mısır'daki parfümlü yağların üretildiği imalathanelere getirildiği zaman, doğru dürüst güvenlik önlemi alınmazdı. İşçilerin bellerine doladıkları kumaşlara bir mühür vurulurdu; ayrıca onlar maske veya sık dokunmuş bir başlık takmak zorundaydılar. İşleri bittikten sonra da herhangi bir hırsızlık olayının meydana gelip gelmediğini öğrenmek için çırılçıplak edilerek üstleri aranırdı. Arap yarımadası, bazı kokuların tabii olarak çıktığı bir yer olması yanında, Afrika ve Hindistan'dan gelen kokuları kuzeye taşıyan kervanların geçtiği ana güzergâhtı. Tevrat'ta verilen bilgiye göre, Yusuf'un kardeşleri tarafından satıldığı İsmâilî (Arap) kervancıların develeri baharat, pelesenk ve mür yüklü idi. Eski Ahid'de, Güney Arabistan'da hüküm sürdüğü düşünülen Sebe kraliçesi Belkıs'ın, Hz. Süleyman'a getirdiği hediyeler arasında bol miktarda baharattan söz edilir. Büyük İskender'in yazılmasını emrettiği Theophrastos'un raporunda ise Sebe ülkesinin (Güney Arabistan) kokuları ile ilgili çok yararlı bilgiler yer almaktadır: Akgünlük de mürr ağacı da fazla büyük değildir; ama bunlardan mürr ağacı daha küçüktür ve dalları yere yakındır. Akgünlük ağacının yaprağı defneyaprağına benzer, ağacın kabuğuysa pürüzsüzdür. Mürr ağacının kabuğu dikenlidir, pürüzsüz değildir. Yaprağı, karaağaç yaprağına benzer; ama kıvrıktır ve ucu kırmız meşesinin yaprağının ucu gibi dikenlidir.. Heropolis'in denizden keşfine katılanlar, su aramak için karaya çıktıklarında akgünlük ve mürr ağaçları ve hasadın ağaçlardan nasıl elde edildiğini gördükleri her iki ağacın gövdesinde baltayla açıldığı anlaşılan kesikler, dallarındaysa derinliği daha az olan kesikler vardı. Reçine damlaları bazen yere düşüyor bazense ağaca yapışıyordu. Bazı yerlerde ağacın altına palmiye yapraklarından örülmüş yaygılar seriliyor, bazı yerlerdeyse zemindeki tozun, kirin temizlenmesi yeterli görülüyordu. Yaygıların üzerindeki akgünlük temiz ve şeffaftı, zemine düşenlerse kötü durumdaydı. Ağaçların demir aletlerle kazınmasıyla elde edilen parçaların bazılarında ağaç kabuğu parçaları vardı. Dağın tamamı Sebe halkına aitti. Sebe halkı dürüst olduğundan dağda bekçi yoktu. Bu nedenle de açgözlülükle biraz akgünlük ve mürrü alıp gemilerine yükleyen bizimkiler, rahatlıkla denize açılabildiler. Dağ, terkedilmiş gibiydi.”. Andrew Dalbi, Tehlikeli Tatlar Tarih Boyunca Baharat, (Çev. Nazlı Pişkin), İstanbul, 2004, s. 183.

${ }^{69}$. Bir çeşit siyah kokudur. Ortaçağda ûd (öd) fiyatları oldukça pahalıydı. Dolayısıyla da tâze ûd buhurdan çok tedavi maksadıyla ilaç olarak kullanılıyordu. Bu türün önemli belirtileri, yumuşaklık ve dilde yakıcılık meydana getirerek onu kabartan bir acılığa sahip olmasıdır. Bu çeşit ûd eğer kurutulursa, o zaman ona "Tâze Râmek" denilirdi, böylece fiyatı düşer ve es-Sanifî çeşidinin fiyatının altına inmiş olurdu. Bkz. ed-Dımaşkî, Ticâretin Güzelliklerine İşâret, (Çev. Abdulhalik Bakır), Ortaçağ Tarih ve Medeniyetine Dair Çeviriler I, Ankara, 2008, s. 491.

${ }^{70}$ Itriyat endüstrisinin bir hammaddesi de kâfûrdur. Kâfûr aynı zamanda zamkların en önde geleni ve en değerlisiydi. Bileşik ilâçların ve parfümlerin yapımında birinci derecede rol oynadığından dolayı, en çok aranan bir ham madde konumundaydı. Hindistan'ın Çin sınırında yer alan Râtec adasında biten kâfûr (Eucaliptus robusta Myrtaceae) ağacının tahtası beyaz ve yumuşaktır, zamkına kâfûr denilmektedir. Gölgesinde yüz kişinin barınabileceği iddia edilen bu ağacın üst kısmında bir delik delinir, sıcağın artmasıyla birlikte içindeki zamk (kâfûr) aşağıya doğru akmaya başlar. Kısa süre sonra, havanın etkisiyle donmuş bir zamk haline gelir. İbn Hurdazbih, kâfûr ağacından elde edilen zamkla ilgili şunları yazmaktadır: "ez-Zâbuc dağlarında bir adamı ve bir 
ISSN-2199-353X

Online only at http://www.cahij.com/

mandayı yutacak kadar büyük yılanlar vardır; hatta onlardan bazıları bir fili bile yutabilir. İşte burada yüz kişinin veya daha fazla veyahut daha azının gölgelenebileceği kâfûr ağacı bulunmaktadır. Bu ağacın üst kısmı delinir; böylece birkaç testi miktarınca kâfûr suyu buradan akmaya başlar, sonra ağacın ortasında ve anılan deliğin tam altında bir delik daha açılır ve buradan kâfûr maddesi akar; akan madde bu ağacın zamkıdır, fakat iç kısmında bulunur. Daha sonra anılan ağaç bırakılır ve böylece kurumaya yüz tutar.”. Bazen kâfûr ağacı, kayalık adalarda ve karanlık ormanlarda bulunurdu. Orman ağaçlarının çok sık ve diğer ağaçlarla sarmaş dolaş olması sebebiyle kimse bu ağacı tanıyamazdı. Kışın ağaçlarda yaprak olmadığından dolayı ancak yaz mevsiminde, hem yapraklardan hem de sıcak nedeniyle onu tespit etmek kolaylaşıyordu. Bu ağaca ulaşmanın zorluklarından biri de çok sayıda yılanın bu ormanlarda barınmasıydı. Zira bu hayvanlar aşırı sıcaktan dolayı, hoş ve hafif rüzgârları kendilerine dokunsun diye kâfûr ağaçlarına dolanırlardı. İnsanlar yaz mevsiminde yüksek tepelere çıkarak tanımış oldukları ağaca bir işaret olması için ok atarlardı. Kış mevsimi gelince, yılanlar deliklere girerler, böylece kim okun değdiği ağacı bulursa o ağaç onun olurdu. Kâfûr ağacının dalları kırmızı olup, çabuk kırılan bir özelliğe sahiptir. Kâfûr o dalların arasında bulunur ve çöpleri parçalanarak aralarından çıkarılırdı. Dışarı çıkarılan bu kâfûra, "fensûrî" denilmekteydi. Bütün kâfûrların ana maddesini oluşturan toz halindeki kâfûra ise "rubâhî" adı verilirdi. Bu zamkın "azâd" ve "esferekü'l-Azrak" (mavi esferek) adında iki çeşidi daha vardır. enNüveyrî, kâfûr çeşitleri ile ilgili şunları yazmaktadır: "Tüccarlar, bir kâfûr ağacında farklı kâfûr türlerinin bulunduğunu iddia etmektedirler. Onlar her türü de kokusuna göre ayırırlar, bunların da üretildiği yerler vardır. Onlardan birisi Fensûr'dur, burası bir ada olup, genişliği yedi yüz fersahtır. Toprağı ise 'Altın toprağı" olarak bilinir, buraya nispet edilen kâfûr, diğer türlerden daha kalitelidir. Üretildiği yerlerden birine de "Erbeşîr" denilir. Çıkarıldığı diğer bir yere de "ez-Zâbuc" adı verilmektedir. Fakat bu sonuncuya nispet edilen kâfûr, en kalitesizi olmaktadır... Kâfûr'un birçok çeşidi vardır: en kalitelisi er-Rubâhî türüdür. er-Rubâhî türünün en kalitelisi ise er-Rubâhî el-Fensûrî denilenidir. Şöyle dediler: Bu türü ancak ağacın tepesinde ve dallarında bulunur, rengi parlak kırmızıdır, sonra oraya çıkar ve ondan beyaz kâfûr oluşur. Bu kâfûr cinsine er-Rubâhî denilmesinin sebebi, Rubâh olarak adlandırılan bir kralın ilk defa onu elde etmesindendir, böylece ona nispet edilmiştir. er-Rubahî cinsinden olan bir türüne de, el-Mehneşân adı verilir, bu ise beyaz, berrak ve el sürüldüğünde yumuşak bir tane şeklindedir, kokusu güzeldir. Onun bir cinsi de el-Bernek olarak bilinir, el sürüldüğünde yumuşaktır, güzel kokuludur, fakat onda el-Mehneşân türünün saflığı yoktur. Sonra onun esSerhân denilen bir türü daha vardır, tanesi, el-Mehneşân tanesinden daha büyüktür, fakat ağacı daha fazladır, rengi siyaha çalar, el sürüldüğ̈̈nde yumuşak olduğu görülür. Onun el-Mutyân denilen yumuşak ve kırmızıya çalan bir çeşidi daha bulunmaktadır. Kâfûr'un parlaklığından dolayı el-Mehây denilen diğer bir türü ise, kırmızı bir taneden ibaret olup, elle ovulduğunda beyaza dönüşür, fakat cevheri kurudur. Bu maddenin bir türü de erRakrak olarak bilinir. el-İsferek denilen bir türü daha vardır, bu ise kaliteli bir kâfûr'dur. Onun bir çeşidine de elKundec denilmektedir, rengi, sâc (tek) ağacının talaşının rengine benzer, fakat bundaki yumuşaklık ve yağlılık yanında tanesinde büyüklük vardır, kırıldığında, içi siyah, elle ovulduğunda ise beyaz görülür. Bütün bu kâfûr çeşitleri ilaç yapımında kullanılır, yalnız Fensûr bölgesinden getirilen er-Rubâhî cinsi hariç, bu ise kalitesi ve güzelliğinden dolayı, özellikle parfüm üretiminde kullanılmaktadır. Ortaçağda kâfûr ağacının çöpleri kaynatılarak suyundan normal kâfûr elde etmek de mümkündü. Bu ise, sarıya çalan beyaz renkli bir kâfûr türüdür. Fakat bu madde dışarıya çıkarılınca, rengi siyahlaşır, yıkanınca da beyaz olur. Bunun yapım tarzı ise şöyledir: Bir miktar taze süt camdan mamul bir kap içine konur. Kâfûrun iri olanları sütün içine atılarak burada yumuşatılır. Sütün süzülmesi ve kâfûrun yerinde kalması için ince bir elek ile elenir. Beyaz ve parlak olması için de bu işlem bir kaç defa tekrarlanır. Fakat çoğunun erimesi için ufaltılmışını yıkamaya gerek yoktur. Aksine bir keten parçası üstüne dökülerek ağzı bağlanır, sonra da taze sütün içine atılır. Kâfûrun en kalitelisi tadı ve kokusu güzel, hafif ve içinde neft (petrol) gibi bir madde bulunmayan kâfûrdur. M. XII. yüzyılda bu vasıflara hâiz olan bir kâfûr "el-cedîd" (yeni, tâze) olarak adlandırılmaktaydı. Bu kalitedeki kâfûr bir miktar arpa ile karıştırılarak bir cam kavanoza konur, ağzı sıkıca kapatılırdı. Ayrıca bu kavanoz her türlü dış etkenden ve özellikle de ateşten ve ısınan cisimlerden iyice korunması gerekirdi. Zira bu madde açık havada kalınca, çürüyüp yok olmaktaydı. Kâfûr'un Ortaçağdaki fiyatlarına gelince; bu konuda sadece nakledilen bir rivayete sahip bulunmaktayız. Kâşânî’nin bu rivayetine göre, M. XIV. yüzyılın başlarında fansûrî ve rubâhî kâfûrların bir menni 300 Tebriz dinarına satılmaktaydı. Normal kâfûrun bir menni ise, 5 dinara alıcı bulmaktaydı. Ortaçağda kâfûr da diğer koku maddeleri gibi, hileli yollarla imal edilmekteydi. Örneğin, bazı ıtriyâtçılar kâfûru, torna talaşından yaparlardı. Onlardan bir kısmı beyaz sakızın (zamk) suyuyla kâfûru yoğurup hamur haline getirirler ve kalburda buharlaştırırlardı. Bir kısım attarlar da kâfûru nişadırdan yaparlardı. Sonra ufacık ufacık kırıp kâfûrla karıştırırlardı. Diğerleri, bu maddeyi öğütülmemiş göz otu (Eup-hrasia officinalis L. Scrophulariaceae)'ndan, söndürülmemiş kireç tozundan ve beyaz zamktan imal ederlerdi. Bazıları da kâfûru parçalanmış, ufaltılmış keçiboynuzu (Ceratonia Siliqua L. Leguminosae)'ndan ve terbiye edilmiş, iyileştirilmiş pirinç (Oryza sativa L. Gramineae)'ten yaparlardı. Bir kısmı ise, onu, yaş hurma çekirdeğiyle döverler, köpük haline geldikten sonra, onu, su ile yoğururlardı. Sonra kâfûr gibi incecik döşerlerdi. Kâfûrun hileli olup olmadığını öğrenmek için bu 
ISSN-2199-353X

Online only at http://www.cahij.com/

yıkanır. Dübür, içine tuz konmuş sirke ve gülsuyu karışımı ile pamuk ıslatılarak, vücut delikleri tıkanır. Burun saf cıva ile doldurulur. Bu da beynin akmasını engeller. Sarısabır, murr, tuz ve şap, vücudun her yanına aynı derecede sürülür. Ceset katran ve bal ile sivanarak kokuşması engellenir." ${ }^{71}$.

\section{Değerlendirme ve Sonuç}

Moğol istilası, Anadolu'da iki asır devam edecek yeni bir dönemin de başlangıcı olmuştur. Moğol istilasının ağır bir şekilde hissedildiği Anadolu Selçuklu devletinin 1308 yılında yıkılmasının öncesinde ve sonrasında, Anadolu'nun merkezi olan Konya ve diğer şehirlerden ve hatta anılan bölgenin kırsal kesimlerinden, uçlara doğru büyük bir göç dalgası ve Moğollardan kaçış başlamıştır. $\mathrm{Bu}$ da ister istemez Anadolu Beylikleri dönemini beraberinde getirmiştir. 1308 yılında son Selçuklu hükümdarının vefatı ile birer birer bağımsızlıklarına kavuşan Anadolu Beylikleri, Selçukluların vârisi olmak için birbiriyle yarışmışlardı. Bu yarış, sadece siyasi ve askeri alanda olmayıp ilim ve imar alanında da kendini göstermiştir. Böylece Anadolu Selçuklu Devletinden devralınan miras, Beylikler döneminde aynı çizgide geliştirilerek birçok yeni kurumun doğmasına zemin hazırlamıştır.

Beylikler ve Erken Osmanlı dönemindeki tıp bilimi ve çalışmalarına inceleyici bir göz atıldığında, şu olumlu ve olumsuz özellik ve faktörleri tespit etmek mümkündür:

1. Beylikler döneminin olumlu özelliklerinden biri, tıp eserlerinin yazımında Türkçenin yoğun bir şekilde kullanılmasıdır. Bu dönemde yazılan eserler özellikle Anadolu Beylerinin isteği üzerine Türkçe kaleme alınmıştır. Ayrıca daha önce yazılan Arapça ve Farsça eserler de Türkçeye tercüme edilerek halkın istifadesine sunulmuştur. Dolayısıyla da bu dönem, Türk dilinin gelişiminin ve yaygın olarak kullanımının gerçekleştiği önemli bir dönem olmuştur.

2. Anadolu Beylikleri döneminde tıp alanında adını duyurmuş birçok ilim erbabından bahsetmek mümkündür. Bu tıp hocaları, kendilerine sunulan imkânlar doğrultusunda sadece hekimlik yapıp eser yazmamışlar, aynı zamanda birçok tabibin de yetişmesini sağlamışlardır. $\mathrm{Bu}$ dönemde gelişme gösteren alanlardan biride eczacılıktır. Farklı bitkilerin hangi hastalıklarda kullanılacağını anlatan bazı eserlerin yazılması yanında, Farmakoloji biliminin de kurumsallaşmasında önemli gelişmelerin yaşandığı bir dönem olmuştur.

3. Beylikler döneminde tıp alanında kaplıcaların da yoğun bir şekilde kullanılmaya başladığını, bu dönem içerisinde beş yüzü aşkın kaplıcanın Anadolu'nun farklı yerlerinde felç vb. hastalıkların tedavisinde hizmet sunduğunu görmekteyiz. Aynı zamanda kaplıcaların birer sağlık kuruluşu haline dönüşmesi de Beylikler döneminde gerçekleşmiştir. Zülkadiroğullarının Kayseri'de özellikle cüzamlı hastalar için kurmuş oldukları ihtisas hastanesi, Beylikler dönemi açısından önemli bir gelişme olarak değerlendirmek gerekir. Zira bu hastalığa yakalanan hastalar anılan döneme kadar hem toplum hem de devlet kurumlarınca tecrit edilmek suretiyle kötü muameleye maruz kalmışlardır. Hatta Kilise de dâhil Ortaçağ Avrupasında cüzam hastalığına yakalanan insanlara, günahkâr oldukları için Tanrı tarafından cezalandırıldıkları gözüyle bakılmıştır.

kokudan birazı suya atılırdı. Atılan şey suyun dibine çökerse hileli, çökmez de suyun yüzünde dönerse halis kâfûr olduğu anlaşılırdı. Bunun diğer bir yöntemi de kâfûrdan birazı bir bez parçasına konur ve ateşin üzerine götürülürdü. Uçar kaybolursa, halis olduğu anlaşılır. Bu işlem sonucunda, ateşte kül bırakırsa, hileli olduğuna karar verilirdi. Bkz. en-Nüveyrî, Nihâyetü'l-Ereb fi Fünûni'l-Edeb, s. 559 (http: www. almeshkat. com/24.07.2006); İbn Hurdazbih, Ebu'l-Kâsım Ubeydullah b. Abdullah, el-Mesâlik ve'l-Memâlik, Bağdat, (Trz.), s. 65; Abdulhalik Bakır, Ortaçağ İslam Dünyasında Itriyat, Gıda, İlaç Üretimi ve Tağşişi, Ankara, 2000, s. 7476.

${ }^{71}$ Bkz. Sezer Erere-Elif Atıcı, Şifâu'l'-Eskâm ve Devâü'l-A'lâm'da Mumyalama, 1. Uluslararası Türk Tip Tarihi Kongresi, 10. Ulusal Türk Tip Tarihi Kongresi Bildiri Kitabı (Ed. Ayşegül Demirhan Erdemir- Öztan Öncel-Yusuf Küçükdağ-Berrin Okka-Sezer Erer), 20-24 Mayıs 2008, Cilt: 2, s. 1784-1785. 
4. Beylikler ve Osmanlı Devleti'nin ilk dönemlerindeki tababetin olumlu yönlerine rağmen, durgunluk ve geçiş dönemi olması hasebiyle birçok pürüz bulunmaktaydı. Örneğin, bu dönemde yazılan eserler iyice incelendiğinde, bilgi olarak Büyük Selçuklu ve Anadolu Selçukluları döneminde yazılan eserlerin bir nevi tekrarından ibaret olduğu görülecektir. Bu dönemde yazılan ve tercüme edilen eserlerin sayısı da daha önceki dönemlere kıyasla azdır. Ayrıca bu dönemde hastalara hizmet veren bîmaristanların büyük bir kısmı, daha önceki dönemlerde inşa edilmiş olup onarılmak suretiyle halkın hizmetine sunulmuştur. Anılan dönemlerde yetişen tabiplerin sayısında da kayda değer bir artış söz konusu değildir. Bu dönemlerde tababetle uğraşan tabiplerin birçoğu ise din âlimlerinden oluşmaktaydı. Tıp okuyarak yetişmiş ve tabiplik mesleğini bir tabip olarak icra edenlerin sayısı da azdı. Dolayısıyla da geleneksel tababet, bilimsel tababetin önüne geçmiş durumdaydı.

Sonuç olarak Beylikler ve Erken Osmanlı dönemlerini, bütün bilim dallarında olduğu gibi, tıp bilimi ve çalışmaları açısından da bir durgunluk ve geçiş dönemi olarak değerlendirmek durumundayız. Zira bu dönemde gerçekleşen Haçlı Seferleri ve Moğol Saldırılar İslam Dünyası coğrafyasını adeta korkunç bir kasırga gibi etki yaparak düzenini bozmuştur. Hayatın her alanı bu olaylardan etkilendiği gibi sağlık alanı da ağır bir şekilde nasibini almıştır. Bu dönemde yazılan tababetle ilgili eserler iyice incelendiğinde İslam dünyasının daha önceki olgunluk döneminin bir kopyasından ibaret olduğu görülecektir. Ancak şunu da unutmamak gerekir ki bu geçiş döneminin sağlik alanındaki en önemli gelişmesi bütün bilim dallarında olduğu gibi, tıp alanında Türkçenin ilim dili haline gelmesidir.

\section{KAYNAKLAR}

\section{Kitaplar}

Adıvar, A. A.; Osmanlı Türklerinde İlim, Remzi Kitapevi, İstanbul, 1982.

Argunşah, M.; Tuhfe-i Murâdî, Inceleme-Metin-Dizin, T. D. K. Y., Ankara, 1999.

Atabek, Emine; Ortaçağ Tababeti, İstanbul, 1977.

Atillâ, Ahmet-Şentürk, Kartal; Eski Türk Edebiyatı Tarihi, Dergâh Yayınları, Ankara 2007.

Bakır, Abdulhalik; Ortaçağ İslam Dünyasında Itriyât, Gıda, İlaç Üretimi ve Tağşişi, Ankara, 2000.

Bakır, Abdulhalik; Ortaçağ İslam Dünyasında Madencilik ve Maden Sanayi, Ankara, 2002.

Banarlı, N. S.; Resimli Türk Edebiyatı Tarihi, M. E. B. Y., İstanbul, 1971.

Bayat, A. H.; Okumuş, N.; Mürşid (Göz Hastalıklarl) Inceleme-Metin-Dizin-Sözlük; Atatürk Kültür Merkezi Yayınları, Ankara, 2004.

Bayat, Ali Haydar; "Uygur Tip Metinleri”, Tip Tarihi, İzmir, 2003.

Bayat, A. H.; Tip Tarihi, Merkezefendi Geleneksel Tıp Derneği, İstanbul, 2010.

Bayat, A. H; "İslam Öncesi Orta Asya Türk Dünyasında Tababet”, Türkler, c. III, Ankara, 2002, s. 808-829.

Bayrakdar, M; İslam'da Bilim ve Teknoloji Tarihi, T. D. V. Y., Ankara, 1985.

Canpolat, M.; Önler, Z.; Edviye-i Müfrede, Türk Dil Kurumu Yayınları, Ankara, 2007.

Dalbi, Andrew; Tehlikeli Tatlar Tarih Boyunca Baharat, (Çev. Nazlı Pişkin), İstanbul, 2004.

ed-Dımaşkî, Ticâretin Güzelliklerine İşâret, (Çev. Abdulhalik Bakır), Ortaçă̆ Traih ve Medeniyetine Dair Çeviriler I, Ankara, 2008, s. 475-540.

Erdemir, A. D; Tip Tarihi Ve Deontoloji Dersleri, Bursa, 1994.

Gürkan, K. İsmail; “Selçuklu Hastaneleri”, Malazgirt Armağanı, TTK yay., Ankara, 1993.

İbn Batûta, Tuhfetu'n-Nüzzâr fi Garâibi'l- Emsâr ve Acâibi'l-Esfâr, Beyrut, (Trz.).

İbn Hurdazbih, Ebu'l-Kâsim Ubeydullah b. Abdullah, el-Mesâlik ve'l-Memâlik, Bağdat, (Trz.).

en-Nüveyrî, Nihâyetü'l-Ereb fi Fünûni'l-Edeb, (http: www. almeshkat. com/24.07.2006).

Öney, G.; Beylikler Devri Sanatı XIV.-XV. Yüzyıl, T. T. K., Ankara, 1989.

Öztuna, Y.; Devletler ve Hanedanlar, C. 5, Kültür Bakanlığı Yayınları Ankara, 1996. 
Sarı, Nil; Tarih Öncesinde Tip, Tıp Tarihi ve Tıp Etiği Ders Kitabı, İstanbul, 2007.

Turan, Osman; Türkiye Selçukluları Hakkında Resmî Vesikalar, Ankara, 1988.

Uludağ, O. Ş.; Beşbuçuk Asırlık Türk Tababeti Tarihi, (Sad: İlter Uzel), Ankara, 1988.

Uzunçarş1l1, İsmail Hakkı; Anadolu Beylikleri ve Akkoyunlu ve Karakoyunlu Devletleri, Türk Tarih Kurumu Yayınları, Ankara 2003.

Ünver, A. S; Selçuk Tababeti XI-XIV üncü Astrlar, T. T. K., Ankara, 1940.

Ünver, A. Süheyl; Osmanl Türklerinde Hekimlik ve Eczacılı, İstanbul, 1952.

Yinanç, M. H.; Türkiye Tarihi, Selçuklular Devri I. Anadolu'nun Fethi, İstanbul, 1994.

Yücel, Y.; Anadolu Beylikleri Hakkında Araştırmalar II, T. T. K., Ankara, 1991.

\section{Yüksek Lisans ve Doktora Tezleri}

Kurban, Ferhat; Şirvanî Mahmud-Sultaniyye (Giriş-Metin-Sözlük), (Yayınlanmamış Yüksek Lisans Tezi), İstanbul Üniversitesi Sosyal Bilimler Enstitüsü, İstanbul, 1990.

Temizel, Ali; Ahmedî'nin Bedâyi'u's-Sihr fì Sanâyi 'i 'ş-Şi'r İsimli Eserindeki Türkçe ve Farsça Şiirleri, Ahmedî’nin Farsça Eserleri-Tenkitli Metin, İnceleme, Tercüme ve İndeks, (Basılmamış Doktora Tezi), Ankara Üniversitesi, Sosyal Bilimler Enstitüsü, Ankara, 2002.

\section{Ansiklopedi Maddeleri}

Kallek, Cengiz, "Kile”, T. D. V. İslam Ansiklopedisi, c. XXV, Ankara, 2002, s. 568-571.

Köprülü, Orhan F.-Uzun, Mustafa; T. D. V. İslam Ansiklopedisi, Akşemseddin Maddesi, İstanbul, 1989, c. II, s. 299-302.

Komisyon, Büyük Larousse Sözlük ve Ansiklopedisi, c. I, s. 57.

Kut, Günay; “Ahmed-i Dâ'̂̂”, T. D. V. İslam Ansiklopedisi, c. II, İstanbul, 1989, s. 56-58.

\section{Makaleler}

Arda, Berna; “Hekim Hayreddin'in Hulâsa Eseri”, Erdem Dergisi, AKM Yayınları, Cilt: 12, Sayı: 34, TTK Basımevi, Ankara, Mayıs 1999, s. 17-26.

Artukoğlu, A., Kaplan, A. ve Yılmaz, A.; "Tıbbi Dokümantasyon”, Bilim ve Teknik Dergisi, Haziran (14). Ankara, 2002, s. 21-29.

Canpolat, Mustafa; "XIV. Yüzyılda Yazılmış Değerli Bir Tıp Eseri Edviye-i Müfrede", Türkoloji Dergisi, V, 1979, s. 21-49.

Çantay, G.; "Bursa'da Osmanlıların İlk Tıp Kurumu”, Erdem, IX (1996), 499-504.

Çiftçioğlu, İ.; Türkiye Selçukluları ve Beylikler Döneminde İlmi Teşvik, İlim Adamlarını Himaye Anlayışı, Ege Üniversitesi Türk Dünyasını Araştırma Enstitüsü, Türk Dünyasını İncelemeleri Dergisi, Say1-1, İzmir, 2006, s. 28-42.

Erer, S.-Atıcı E.; "Selçuklu ve Osmanl1larda Müzikle Tedavi Yapılan Hastaneler", Uludă̆ Üniversitesi Tip Fakültesi Dergisi, 36 (1), Bursa, 2010, s. 29-32.

Kayhan, Hüseyin; Beylikler Devrinde Tıp Bilimi ve Hekimler, History Studies, Volme 2/3 2010, s. 223-229.

Uzel, İ.-Süveren, K.; “İlk Türkçe Tıp Yazmalarına Genel Bir Bakış”, Tıp Tarihi Araştırmaları Dergisi, Say1 2, İstanbul, 1988, s. 131-144.

Ünver, S.; “Anadolu Selçuklularında Sağlık Hizmetleri”, Malazgirt Armağanı, Ankara, 1972, s. 9-31.

\section{Bildiriler}

Altıntaş, Ayten-Arkadaşları; İ̉n Şerif, Yâdigâr, (Tabîb İbn-i Şerîf); 2 Cilt, 5. Merkez Efendi Geleneksel Tip Günleri Anısına (14-22 Mayıs 2004), Yerküre Yay., İstanbul, 2004, s. 91-102. 
Erdemir, Ayşegül Demirhan; Uluğ Bey Döneminde (15. YY) Osmanlı Tıbbından Bir Örnek: İbn Şerif'in Yâdigâr Adlı Eserinin Tiryakla İlgili Bazı Bilgiler ve Orijinal Sonuçlar, Uluğ Bey ve Çevresi Uluslararası Sempozyumu Bildirileri, (Ankara, 30 Mayıs-1 Haziran 1994), (Yay. Haz. Songül Boybeyi), Ankara, 1996, s. 123-128.

Erer, Sezer-Atıc1, Elif; Şifâu'l-Eskâm ve Devâü'l-A'lâm'da Mumyalama, 1. Uluslararası Türk Tip Tarihi Kongresi, 10. Ulusal Türk Tip Tarihi Kongresi Bildiri Kitabı (Ed. Ayşegül Demirhan ErdemirÖztan Öncel-Yusuf Küçükdağ-Berrin Okka-Sezer Erer), 20-24 Mayıs 2008, Cilt: 2, s. 1783-1787.

Erkan M, Şahin S.; “Türklerde Müzikle Ruh ve Sinir Hastalıklarının Tedavisi”, Kayseri Üniversitesi Gevher Nesibe Bilim Haftası ve Tip Günleri, Kayseri 11-13 Mart 1982, s. 572-579.

Güreşsever, G. C.; "Osmanlı Türklerinde Tıp Eğitimi”, Osmanlı Devletinde Sağllk Hizmetleri Seтроzуuти, Haz., Bilal Ak-Adnan Ataç, Ankara 2000, s. 125-134.

Kâhya, Esin; Onbeşinci Yüzyılda Yaşamış bir Hekimimiz Mümin Mukbil, I. Türk Tıp Kongresi, Kongreye Sunulan Bildiriler, İstanbul, 17-19 Şubat, 1988, Ankara, 1992, s. 93-102.

Kaya, E.; “Safa Odabaşı'nın Arşivindeki Türkçe Tıp Yazmaları”, I. Edirne Tıp Tarihi Günleri Bildirileri (3-4 Ekim 2001) "Dr. Rifat Osman Anısına" (1874-1933), (Haz. Ender Bilar), Trakya Üniversitesi Rektörlüğ̈̈ Yayınları No: 42, Edirne, 2001, s. 383-296.

Yalın, Cevat; 15. Yüzyılda Osmanlılarda Kulak Hastalıkları Tedavi ve Cerrahisi, I. Türk Tıp Tarihi Kongresi, Kongreye Sunulan Bildiriler, İstanbul, 17-19 Şubat 1988, Ankara, 1992, s. 103-104.

\section{İnternet Siteleri}

www.aksaray.gov.tr. 